ARCHIWA - KanCELARIE - ZBIORY

NR 6(8)/2015

Magdalena WiśniewsKA

Uniwersytet Mikotaja Kopernika

\title{
AMERYKAŃSCY ARCHIWIŚCI O ORAL HISTORY - PRZEGLĄD TEMATYKI TEKSTÓW PUBLIKOWANYCH W DRUGIEJ POŁOWIE XX WIEKU NA ŁAMACH „AMERICAN ARCHIVIST”
}

http://dx.doi.org/10.12775/AKZ.2015.001

Słowa kluczowe

oral history; historia mówiona; American Archivist; archiwistyka amerykańska;

Keywords

oral history; American Archivist; American archival science

Streszczenie

Artykuł w swej pierwszej części zawiera szczegółowe omówienia osiemnastu tekstów dotyczących historii mówionej, opublikowanych w czołowym amerykańskim czasopiśmie archiwistycznym „American Archivist” w drugiej połowie XX wieku. Na drugą część składają się wnioski dotyczące obecności tematyki historii mówionej w dyskursie archiwistycznym w Stanach Zjednoczonych Ameryki Północnej w drugiej połowie XX wieku. Najwięcej miejsca poświęca się w analizowanych opracowaniach tematowi charakteru relacji oral history jako źródeł historycznych. Poruszana jest zwłaszcza kwestia wiarygodności historii mówionej oraz sposobów jej zapewnienia (m.in. przez odpowiedni opis). Ponadto w wielu przypadkach teksty te próbują 
przekonać historyków do wykorzystywania historii mówionej w badaniach. Można zauważyć również, że w pewnym momencie zmienia się rozumienie oral history jako źródła historycznego - właściwym źródłem staje się samo nagranie wywiadu, audio lub wideo, a nie notatki sporządzone w jego trakcie lub też jego transkrypcja. Ważne miejsce w rozważaniach amerykańskich autorów zajmują relacje między historią mówioną a dokumentacją tradycyjną (papierowa). $\mathrm{Z}$ analizy artykułów wynika też, że autorzy zajmowali się przede wszystkim zagadnieniami natury historycznej, a w mniejszej mierze - archiwistycznej. Wśród tych drugich natomiast najczęściej pojawiają się tematy związane z udostępnianiem materiałów oral history. Poruszana jest jednak również kwestia miejsca archiwów i archiwisty w działalności związanej z nagrywaniem oral history; całkowicie brak omówienia problemu przechowywania materiałów oral history.

] ak każda dyscyplina naukowa, również i archiwistyka ewoluuje. Jednym co pokazało m.in. ostatnie spotkanie archiwistów w ramach cyklu „Toruńskie Konfrontacje Archiwalne”" . Od pewnego czasu w polskim dyskursie archiwistycznym zadomowiły się (a właściwie może dopiero „zadomawiają się”) tematy takie jak archiwistyka społeczna czy egodokumentalność zasobów archiwalnych. Uważam, że dość naturalną konsekwencją tego jest zajęcie się z perspektywy naszej profesji zagadnieniem historii mówionej.

Polscy archiwiści w niewielkiej mierze podjęli się do tej pory opisania zagadnienia relacji oral history ${ }^{2}$ jako obiektu archiwalnego ${ }^{3}$. Dzięki analizie rozwoju „myśli oral history” wśród amerykańskich archiwistów, działających w kraju o najstarszych bodaj tradycjach historii mówionej, możliwe będzie podjęcie tej tematyki w polskiej myśli archiwalnej nie zaczynając od początku, ale ucząc się już na pewnych doświadczeniach kolegów zza oceanu. Może

${ }^{1}$ Patrz: Toruńskie Konfrontacje Archiwalne, t. IV: Nowa archiwistyka - archiwa i archiwistyka w ponowoczesnym kontekście kulturowym, red. W. Chorążyczewski, W. Piasek, A. Rosa, Toruń 2014.

2 Ponieważ piszę po polsku o tekstach pisanych w języku angielskim, pojawiają się pewne rozbieżności terminologiczne. Artykuł jednak samej terminologii nie dotyka, dlatego zastosowałam uproszczenia w kwestii kluczowych wyrażeń, co zresztą ułatwiło proces pisania niniejszego tekstu. Synonimicznie potraktowałam następujące terminy: oral history $=$ historia mówiona; relacja $=$ wywiad $($ ang. interview $)=$ wspomnienie $($ ang. reminiscence); udzielający wywiadu (ang. interviewee $)=$ świadek historii $=$ narrator $=$ relator.

3 Patrz: A. Żeglińska, Relacje oral history jako obiekty archiwalne, Archiwa - Kancelarie - Zbiory, nr 2(4)/2011, s. 145-154. 
to pomóc polskim naukowcom nie tyle w stworzeniu gotowych odpowiedzi, ale przede wszystkim najpierw w sformułowaniu pytań o obecność relacji historii mówionej w polskich instytucjach kultury.

Północnoamerykańska literatura dotycząca oral history, również ta stricte naukowa, jest wręcz niezmierzona i sama mogłaby być tematem ogromnego badania. Postanowiłam jednak przyjrzeć się zagadnieniu historii mówionej z perspektywy archiwistyki. W tym celu w niniejszym artykule przedstawiam analizę tekstów dotyczących oral history opublikowanych na łamach czasopisma „American Archivist” w drugiej połowie XX wieku. Naturalnie można mi zarzucić, że po pierwsze, amerykańscy archiwiści publikowali w innych czasopisma i w ogóle w innych publikacjach (również samodzielnych), a po drugie (co widoczne będzie w dalszej części artykułu, w trakcie analizy konkretnych tekstów), że to, iż czasopismo ma w nazwie słowo pochodzące z, tak to nazwijmy, archiwistycznej rodziny wyrazów, nie musi od razu oznaczać, że każdy tekst jest napisany przez kogoś zawodowo zajmującego się archiwistyką lub że tekst prezentuje jakieś zagadnienie stuprocentowo z perspektywy nauki archiwalnej, zwłaszcza w takim kształcie, w jakim rozumiemy ją dziś. Trudno się z tym nie zgodzić. Przyznaję, że w trakcie badań nad tym zagadnieniem przyjęłam dość upraszczające sprawę założenie, że „American Archivist” jest na tyle poczytnym i szanowanym czasopismem (wydawanym zresztą już od roku 1938), że w pewnym stopniu reprezentuje jeśli nie konkretne, szczegółowe poglądy, to choć pewne zainteresowania badawcze amerykańskiego środowiska archiwistycznego. Choć naturalnie, co podkreślam jeszcze raz, jest to uproszczenie sprawy i nie należy zakładać, że trendy zauważalne w czasopiśmie (a nawet ogólnie - w piśmiennictwie naukowym) odzwierciedlają rzeczywiste myślenie Amerykanów, zwłaszcza że z całą pewnością istniała rozbieżność między poglądami środowiska naukowego a praktyką działalności dokumentacyjnej.

Niniejszy artykuł składa się z dwóch zasadniczych części. Pierwsza z nich zawiera omówienie, w porządku chronologicznym, głównych treści artykułów dotyczących wyłącznie (lub w dużej mierze) oral history. W analizie pominięto teksty, w których temat historii mówionej został poruszony, jednak nie zajmował on zbyt wiele miejsca i nie był centralnym problemem publikacjí ${ }^{4}$.

${ }^{4}$ H.E. Edmunds, The Ford Motor Company Archives, American Archivist, Vol. 15, No. 2, April 1952, s. 99-104; V.D. Bornet, The Manuscripts of Social Welfare, American Archivist, Vol. 23, No. 1, January 1960, s. 33-48; W.J. Stewart, The Sources of Labor His- 
Od tej zasady zastosowałam jednak dwa wyjątki. Otóż postanowiłam zanalizować również teksty, w których oral history nie gra kluczowej roli, ale uznałam, że mimo tego warto o nich wspomnieć. Chodzi o artykuł F.G. Hama, „The Archival Edge”, który traktuje m.in. o selekcji archiwalnej i działalności dokumentacyjnej archiwów (i w jej ramach o relacjach historii mówionej), oraz o tekst J. Capona Lestera będący komentarzem do tekstu Hama. Prezentacja zanalizowanych przeze mnie artykułów jest dość szczegółowa i obszerna, gdyż sądzę, że w przyszłości może ewentualnie posłużyć jako źródło samo w sobie, zwłaszcza że teksty z „Amerykańskiego Archiwisty” nie są nigdzie przetłumaczone na język polski. Być może ten artykuł przysłuży się komuś, kto nie zdołał przebrnąć przez barierę językową i dotrzeć do tekstów oryginalnych. W części drugiej opisano pewne prawidłowości związane z obecnością tematyki oral history w „American Archivist”, które udało mi się dostrzec na podstawie analizy tekstów ukazanej w pierwszej części tego artykułu.

tory: Problem and Promise, American Archivist, Vol. 27, No. 1, January 1964, s. 95-102; J.A. Popplestone, M. White MacPherson, The Archives of the History of American Psychology, American Archivist, Vol. 34, No. 1, January 1971, s. 13-19; E. Moseley, Women in Archives: Documenting the History of Women in America, American Archivist, Vol. 36, No. 2, April 1973, s. 215-222; D.E. Kyvig, Family History: New Opportunities for Archivists, American Archivist, Vol. 38, No. 4, October 1975, s. 509-519; D.H. Culbert, Family History Projects: The Scholarly Value of the Informal Sample, American Archivist, Vol. 38, No. 4, October 1975, s. 533-541; R.N. Juliani, The Use of Archives in the Study of Immigration and Ethnicity, American Archivist, Vol. 39, No. 4, October 1976, s. 469477; R.L. Filippelli, Collecting the Records of Industrial Society in Great Britain: Progress and Promise, American Archivist, Vol. 40, No. 4, October 1977, s. 403-411; W.T. Hagan, Archival Captive - The American Indian, American Archivist, Vol. 41, No. 2, April 1978, s. 135-142; D.H. Fenn, Jr., Launching the John F. Kennedy Library, American Archivist, Vol. 42, No. 4, October 1979, s. 429-442; L.J. Henry, Collecting Policies of Special-Subject Repositories, American Archivist, Vol. 43, No. 1, Winter 1980, s. 57-63; E.S. Moseley, Sources for the „New Women's History”, American Archivist, Vol. 43, No. 2, Spring 1980, s. 180-190; F.M. Miller, Social History and Archival Practice, American Archivist, Vol. 44, No. 2, Spring 1981, s. 113-124; T.H. Kreneck, Documenting a Mexican American Community: The Houston Example, American Archivist, Vol. 48, No. 3, Summer 1985, s. 272-285; R.J. Anderson, Managing Change and Chance: Collecting Policies in Social History Archives, American Archivist, Vol. 48, No. 3, Summer 1985, s. $296-$ -303; S. Mbaye, Oral Records in Senegal, American Archivist, Vol. 53, No. 4, Fall 1990, s. 566-574; F. Phillips, Congresional Papers: Collection Development Policies, American Archivist, Vol. 58, No. 3, Summer 1995, s. 258-269; J.-P. Wallot, Archival Oneness in the Midst of Diversity: A Personal Perspective, American Archivist, Vol. 59, No. 1, Winter 1996, s. 14-29; J. Mifflin, „Clothing Facts in Words”: Archivists and the Holocaust, American Archivist, Vol. 61, No. 2, 1998, s. 453-474. 
Pomiędzy rokiem 1955 (pierwszy artykuł o oral history) a 1991 (ostatni taki w badanym okresie) na kartach „American Archivist” ukazało się 14 artykułów, 1 raport i 1 wywiad dotyczące wyłącznie lub w dużej mierze tematyki historii mówionej. Ponadto w mojej analizie znalazły się dwa wymienione wcześniej wyjątki (artykuły Hama i Lestera). W sumie daje to 18 zanalizowanych tekstów. Rozłożenie ich w ramach dekad wygląda następująco: lata 50. 3 teksty, lata 60. -5 tekstów, lata 70. -5 tekstów, lata 80. -4 teksty, lata 90. - 1 tekst, przy czym wśród pięciu tekstów z lat 60. aż 4 pochodzą z numeru ze stycznia 1965 roku, w którym to numerze istniał specjalny dział zatytułowany „Oral history”.

Pierwszym artykułem opublikowanym na łamach „American Archivist” poświęconym historii mówionej jest tekst Vaughna Davisa Borneta „Oral history can be worthwhile” („Historia mówiona może być warta zachodu”) z roku $1955^{5}$. Autor rozpoczyna swą publikację od konkretnego określenia, jak rozumie on oral history. „Oral history to ustne wspomnienia, które zostały zapisane z pomocą odpowiednio przygotowanego historyka przeprowadzającego wywiady, w zgodzie z uznawanymi standardami etycznymi i proceduralnymi i spisane [na maszynie, w oryg. typewritten - przyp. MW] pod jego nadzorem" ". Następnie podkreśla, że nietrzymanie się tych standardów sprawia, że nagrana i transkrybowana rozmowa typu pytanie-odpowiedź jest zwyczajnym wywiadem, a nie oral history, a także, że relacje oral history stworzone w sposób nieodpowiedzialny mogą być źródłami, które sprawią historykom wiele problemów ${ }^{7}$. Autor zastanawia się nad miejscem historii mówionej w badaniach historii ostatnich 55 lat; podkreśla, że nie może się ona równać z autentycznym dziennikiem, współczesnym raportem giełdowym czy zeznaniem naocznego świadka spisanym w dzień wydarzenia; jednocześnie mówi, że oral history jest ponad dowodami pochodzącymi z pogło$\mathrm{sek}^{8}$. Bornet zauważa, że „Trwałość transkryptu wywiadu oral history kładzie szczególną odpowiedzialność na rzemieślnikach, którzy wywołują te wspomnienia jako depozyt dla bibliotek i archiwów"

5 V.D. Bornet, Oral history can be worthwhile, American Archivist, July 1955, Vol. 18, No. 3, s. 241-253.

6 Tamże, s. 241.

7 Tamże.

8 Tamże, s. 244.

9 Tamże, s. 247. 
Następnie autor artykułu przechodzi do zaproponowania standardów powstawania historii mówionej, które w jego mniemaniu są bardzo istotne i ich sformułowanie powinno nastąpić niezwłocznie ("Standards for the Manufacture of Reminiscences With a Recording Device” - „Standardy wytwarzania $^{10}$ wspomnień z użyciem urządzenia rejestrującego"). Cele stosowania takich standardów to: nietracenie czasu osób udzielających wywiadu; przyciąganie funduszy; zadowolenie przyszłych historyków; chronienie opinii publicznej przed dostarczeniem jej nierzetelnych czy mylących informacji o przeszłości ${ }^{11}$.

Według Borneta dobrą praktyką jest zachowywanie oryginalnych taśm czy też dysków, aby można było przetranskrybować tekst; podaje, na jakim sprzęcie powinno się nagrywać krótkie fragmenty wypowiedzi narratora, aby dać użytkownikowi próbkę jego głosu (zwraca uwagę na potrzebę istnienia nagrania wysokiej jakości) ${ }^{12}$. Transkrypcja wywiadu powinna zostać opatrzona następującymi informacjami: imię i nazwisko narratora; imię i nazwisko, wiek i zawód osoby przeprowadzającej wywiad; data i czas każdej z sekcji wywiadu; dokładne miejsce przeprowadzenia wywiadu; nazwiska osób edytujących i piszących transkrypcję. Ponadto na początku transkrypcji powinna znajdować się krótka notatka o narratorze, a także informacja, dlaczego skontaktowano się z daną osobą; czy poinformowano ją o wywiadzie zawczasu i czego będzie dotyczył - jakiej części jego życia; czy narrator „odświeżał” sobie pamięć jakimiś wydawnictwami lub rozmowami z innymi świadkami historii ${ }^{13}$. Po wywiadzie osoba go przeprowadzająca może napisać notatkę na temat jego przebiegu: jakie było podejście narratora, czy, a jeśli tak to kiedy miał on momenty zawahań, jaka była jego energiczność, w co był ubrany i jak wygląda $1^{14}$.

Słowa wywiadu powinny być zapisane dokładnie tak, jak je wypowiedziano lub jak je poprawił narrator; do transkrypcji należy dodać informację, co i jak poprawiono. Finalna wersja transkrypcji powinna zawierać zarówno py-

10 Niestety, po polsku to słowo nie brzmi w tym kontekście zbyt fortunnie. Naturalnie nie chodzi tutaj o tworzenie, fabrykowanie jakichś nieistniejących dotąd wspomnień, ale o ich transmisję z formy „ulotnej” do pewnego zapisu - taki jest cel tej „manufaktury".

11 V.D. Bornet, dz. cyt., s. 247.

12 Tamże.

13 Tamże, s. 248.

14 Tamże, s. 248-249. 
tania, jak i odpowiedzi ${ }^{15}$. Autor opisuje również, jak powinno się przeprowadzać wywiad, jak powinien zachować się pytający, np. nie okazywać emocji, nie sugerować odpowiedzi, nie ujawniać swojej osobowości, myśli, pragnień, uprzedzeń, aby nie wpływać na to, co mówi narrator ${ }^{16}$.

Bornet w swojej propozycji zestandaryzowanych procedur omawia też zagadnienia praw autorskich i udostępniania relacji. Relator nie powinien wydawać transkrypcji jako swoich wspomnień lub autobiografii przez 5 lat po udzieleniu wywiadu ${ }^{17}$; powinien on otrzymać kopię transkrypcji, ale oryginał (podpisany) powinien zostać własnością organizacji oral history i być na równych zasadach udostępniany naukowcom ${ }^{18}$. Autor zaleca, aby narrator udzielał wszystkim przyszłym korzystającym pisemnego zezwolenia na cytowanie i kopiowanie transkryptu (bez czerpania z tego zysków). Zaistnienie transkrypcji relacji powinno zostać zakomunikowane w czasopismach historycznych lub archiwistycznych, a ich udostępnianie powinno rozpocząć się jak najszybciej ${ }^{19}$.

Autor artykułu uważa, że relacje oral history mogą pomóc wypełnić pustkę po niepisanych już obecnie pamiętnikach i nieprowadzonej (na rzecz rozmów telefonicznych) korespondencji ${ }^{20}$. Podkreśla on, że „Wspomnienia oral history mogą być warte zachodu, ale tylko jeśli przygotowywane są z wyrobioną dbałością i wykorzystywane z akademicką rozwagą" ${ }^{21}$. Według Borneta standardów w postępowaniu z historią mówioną trzeba przestrzegać zwłaszcza dlatego, że niewielu historyków i archiwistów jest przekonanych o wysokiej wartości oral history jako źródła ${ }^{22}$.

Następnym chronologicznie tekstem o historii mówionej opublikowanym w „American Archivist” jest artykuł Helen McCann White „Thoughts

15 Tamże, s. 249.

16 Tamże, s. 250.

17 Jak tłumaczy Bornet, chodzi o zapobieżenie sytuacji, gdy osoba przeprowadzająca wywiad traktowana jest jako darmowy ghostwriter - tamże, s. 251.

18 Tamże, s. 250-251.

19 Tamże, s. 251.

20 Tamże, s. 253; o tego typu obawach - dotyczących braku pewnych rodzajów źródeł w związku z rozwojem technologicznym - pisał również w kontekście rozwoju północnoamerykańskich praktyk oral history R.J. Grele; patrz: M. Fiternicka-Gorzko, Historia mówiona: od metody historycznej do interdyscyplinarnego podejścia badawczego, Opuscula Sociologica, nr 2/2012, s. 8.

21 V.D. Bornet, dz. cyt., s. 254.

22 Tamże. 
on oral history” („Przemyślenia dotyczące oral history”) z roku $1957^{23}$. Autorka rozwiewa wątpliwości terminologiczne: „Szeroki termin oral history w tym artykule odnosi się do ustnego historycznego świadectwa uzyskanego przez przeszkolonych historyków zajmujących się wywiadami; zapisanego przez nich lub pod ich kierownictwem, odręcznie, maszynowo lub z użyciem sprzętu nagrywającego; zachowanego zarówno w swej oryginalnej formie, jak i w formie pisanego na maszynie transkryptu skolacjonowanego $\mathrm{z}$ oryginałem. Termin wywiad oral history opisuje konkretną formę oral history - ustne wspomnienie zapisane na taśmie z pomocą wyszkolonych historyków zajmujących się wywiadami i przetranskrybowane do formy maszynopisu, zgodnie ze standardami etycznymi i proceduralnymi" ${ }^{\prime 2}-\mathrm{w}$ tym miejscu znajduje się przypis do omówionego powyżej tekstu V.D. Borneta z 1955 roku.

W artykule autorka opisuje działalność the Forest history Foundation, Inc. zajmującej się m.in. gromadzeniem relacji osób związanych swą działalnością z lasami oraz przemysłem drzewnym ${ }^{25}$. Fundacja ta zorganizowała 10-tygodniowy program polegający na poszukiwaniu dokumentów pisanych dotyczących tematu oraz zbieraniu relacji od osób pamiętających firmy, dokumenty i wydarzenia związane z „leśną historią” [ang. forest history]. Program ten trwał w sierpniu, wrześniu i październiku 1955 roku. Autorka pomagała w przeprowadzaniu wywiadów oral history podczas tego programu. Najpierw przeprowadzono 99 wywiadów (w tym część przez telefon), dzięki którym wytypowano 25 osób uznanych za dobre obiekty do przeprowadzenia z nimi dalszych wywiadów oral history; z piątką spośród nich przeprowadzono zarejestrowane [tape-recorded, nagrane na taśmę] wywiady historii mówionej ${ }^{26}$.

Autorka formułuje kroki, które powinny być kolejno przedsiębrane w celu uzyskania jak najdoskonalszej produkcji historii mówionej. Pierwszy krok to przygotowanie się do wywiadu; przeprowadzający go powinien poznać historię, temat oraz miejsce, którego ma dotyczyć rozmowa, a ponadto znaleźć kogoś, kto może być drogą do innych relatorów i znajomości ${ }^{27}$. Kolejny krok to

23 H. McCann White, Thoughts on oral history, American Archivist, January 1957, Vol. 20, No. 1, s. 19-30.

24 Tamże, s. 19.

25 Fundacja z czasem przekształciła się w stowarzyszenie, the Forest history Society, które działa po dziś dzień. Patrz: History of the Forest History Society, http://forest history. org/About/fhshistory.html [dostęp dnia 2.11.2014 r.].

26 H. McCann White, dz. cyt., s. 19-20.

27 Tamże, s. 21-22. 
wstępne wywiady w terenie, a dopiero potem na ich podstawie wybranie tych osób, z którymi chcemy przeprowadzić i nagrać wywiad oral history. Potem następuje przeprowadzenie (i nagranie) wywiadu oraz jego transkrypcja i korekta. Ostatni krok to sformułowanie warunków umowy, zawierającej kwestie własności relacji oraz jej użycia (udostępniania) ${ }^{28}$.

Helen McCann White podaje również, do czego mają służyć historykom tak pozyskane relacje. „[...] wraz z pamiętnikami, aktami sądowymi, tabelami spisu ludności, miejskimi książkami telefonicznymi, gazetami i dokumentacją biznesową - do odtworzenia obrazu życia w dolinie ${ }^{29}$ podczas złotego okresu rozwoju przemysłu drzewnego" 30 .

Autorka sugeruje pewne rozwiązania, których zastosowanie sprawi, że relacja będzie miała większą wartość historyczną. Częścią każdego wywiadu muszą być podane przez relatora informacje dot. jego biografii; narrator w trakcie opowieści powinien również opowiedzieć o tym, jakie materiały źródłowe posiada, zna, których używał. Należy nagrać na taśmie również miejsce, czas, uczestników i innych wymienionych w relacji, podobnie jak pozostałe informacje potrzebne w procesie katalogowania. Osoba przeprowadzająca wywiad nie powinna zadawać pytań naprowadzających, a także nie może wkładać własnych słów w usta opowiadającego ${ }^{31}$.

W przypadku sporządzenia transkryptu autorka zaleca przesłanie jednej kopii do narratora, w celu naniesienia przez niego poprawek na tekst ${ }^{32}$. Poprawki może nanosić również osoba przeprowadzająca wywiad. „Podstawowym obowiązkiem przeprowadzającego wywiad w trakcie tworzenia transkryptu jest wyjaśnienie myśli [narratora - przyp. MW] przy jak najmniejszej ingerencji w tekst ${ }^{33}$ ".

Autorka zastanawia się, czy po sporządzeniu transkryptu i ustaleniu „wspólnej wersji” relacji należy zatrzymać nagranie, czy też je zniszczyć. „[...] jeśli w transkrypcie dokonano wielu zmian. Prawdopodobnie lepiej wtedy całkowicie usunąć nagranie z taśmy, niż zachowywać niedoskonałą wersję wy-

28 Tamże, s. 20.

29 Chodzi w tym wypadku o Dolinę St. Croix (St. Croix Valley).

30 H. McCann White, dz. cyt., s. 23-24.

31 Tamże, s. 25.

32 Tamże, s. 26-27.

33 Tamże, s. 27. 
wiadu ${ }^{34}$. Wyczyszczone taśmy mogą być użyte wielokrotnie. $\mathrm{Z}$ drugiej jednak strony zachowywanie taśm z oral history jest zachowywaniem oryginalnych źródeł, głosów, cząstek osobowości i atmosfery wywiadu”" ${ }^{35}$. The Forest history Foundation zaproponowało rozwiązanie polegające na przegrywaniu i zachowywaniu fragmentów z każdego wywiadu. Przed skasowaniem nagrań fundacja oferuje narratorowi wykupienie taśm za równowartość nowych nośników - to było bowiem podstawową barierą - cena taśm, na których nagrywano relacje ${ }^{36}$. Dziwić może jednak inne rozwiązanie: „Jeśli taśmy zawierające wywiad oral history mają być zachowane przez udzielającego wywiadu lub jego rodzinę, wtedy powinny być poprawione, tak, aby zgadzały się z zaaprobowanym transkryptem i powinny podlegać tym samym warunkom umowy w sprawie ich użycia, które wypracowano między przeprowadzającym i udzielającym wywiadu w sprawie warunków użycia transkryptu" ${ }^{37}$.

McCann White zajmuje się również kwestią publiczności historii mówionej i zagadnieniem, do kogo ona należy. „Przeprowadzający wywiad chciałby tworzyć wywiad oral history pierwotnie dla swego własnego użytku, jednak zdaje sobie sprawę z obowiązku zachowania go jako źródła historycznego dla użytku innych”38. „Opisana tutaj metoda oral history należy do takich, w których przeprowadzający wywiad i udzielający go współpracują, podejmując próbę stworzenia obiektywnej, prawdomównej, wiernie zapisanej i dokładnie przetranskrybowanej historii mówionej. Ich wytwór, wywiad oral history, dobrowolnie poświęcają na użytek historii"39.

Kolejny artykuł to opublikowany w tym samym, 1957, roku tekst Corinne Lathrop Gilb „Tape-Recorded Interviewing: Some Thoughts From California” („Przeprowadzanie rejestrowanych na taśmie wywiadów: przemyślenia z Kalifornii" ${ }^{40}$. W przeciwieństwie do dwóch poprzednich osób, autorka nie zaczyna tekstu od zdefiniowania oral history (ta problematyka w tym tekście w ogóle się nie pojawia). Stwierdza natomiast, że mimo ogromu różnego

${ }^{34}$ M.in. o praktyce redagowania i korekty wywiadów patrz: M. Fiternicka-Gorzko, dz. cyt., s. 8.

${ }^{35}$ H. McCann White, dz. cyt., s. 28.

36 Tamże.

37 Tamże.

38 Tamże, s. 29.

39 Tamże, s. 30.

${ }^{40}$ C. Lathrop Gilb, Tape-Recorded Interviewing: Some Thoughts From California, American Archivist, October 1957, Vol. 20, No. 4, s. 335-344. 
rodzaju produkowanych dokumentów „wewnętrzne prace instytucji społecznych, ważne wydarzenia i dwudziestowieczny człowiek jako taki zazwyczaj pozostają nieudokumentowane”ł1 . Podkreśla również brak pisanej niegdyś powszechnie długiej korespondencji i pamiętników ${ }^{42}$.

Artykuł dość obszernie porusza kwestię odnalezienia się zawodu historyka w rzeczywistości historii mówionej. Autorka opisuje, jak widzi wykorzystanie oral history przez naukowców: „aby pomóc udokumentować nieudokumentowane i by rzucić nowe światło na to, co już zostało zapisane, nagrywane wywiady mogą być prawdziwym skarbem dla badaczy, współczesnych i przyszłych" ${ }^{\prime 3}$. Corinne Lathrop Gilb zaznacza, że technika wywiadu nie jest nową metodą zbierania danych naukowych; podkreśla jednak różnicę między historykiem zbierającym oral history a innymi naukowcami: „Historyk oralny ${ }^{44}$ jest tylko w tym wyjątkowy, że tworzy swoje wywiady dla innych ludzi, aby użyli ich kiedyś w przyszłości i tym samym boryka się on z wyjątkowymi pro-

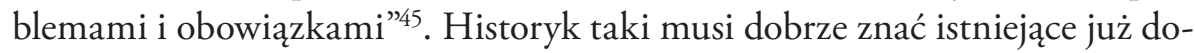
kumenty pisane, aby wywiadami nie powielać tego, co już opisano w różnego rodzaju obiektach przechowywanych w archiwach czy bibliotekach; tym samym musi najpierw znaleźć luki w dokumentacji i na tej podstawie wybrać temat swych poszukiwań. Historyk oralny musi ponadto przewidzieć, czym będą zainteresowane przyszłe pokolenia badaczy ${ }^{46}$.

Autorka pisze: „Tylko sobie wyobraźcie, jakie wejrzenia w dwudziestowieczną kulturę amerykańską można by uzyskać dzięki wnikliwej i szczegółowej eksploracji myśli i doświadczeń takich osób jak Dave Beck, Billy Graham, Al Capone, czy William Faulkner"’7. Jest to zdanie zdecydowanie zabarwione „amerykańskim podejściem” do oral history, które zakładało (zwłaszcza w początkach rozkwitania dyscypliny/metody) pozyskiwanie wspomnień od osób znanych, wybitnych, już za życia mających duży wpływ na bieg historii, tzw. movers and shakers ${ }^{48}$; w opozycji niejako staje podejście

41 Tamże, s. 335.

42 Tamże.

43 Tamże.

44 Używany przeze mnie w niniejszym tekście termin „historyk oralny” jest właściwie kalkowym tłumaczeniem angielskiego zwrotu „oral historian” - chodzi o historyka stosującego metodę oral history.

45 C. Lathrop Gilb, dz. cyt., s. 336.

46 Tamże, s. 337.

47 Tamże, s. 338.

48 Patrz: M. Fiternicka-Gorzko, dz. cyt., s. 8. 
brytyjskie, czy raczej szerzej - europejskie - tzw. history from below, które skłaniało się ku zwróceniu uwagi na ludzi zwyczajnych ${ }^{49}$.

Według Lathrop Gilb wywiad powinien dotyczyć całego życia danego człowieka, ponieważ może pomóc to w interpretacji słów i czynów podejmowanych w przeszłości i opisanych przez narratora, przez pryzmat jego przeszłych przeżyćs ${ }^{50}$. Autorka ponadto opisuje procedury przeprowadzania wywiadów w Uniwersytecie Kalifornii (podkreśla, że są takie, jak wcześniej opisano w „American Archivist”). Zaznacza obecność przygotowania czynionego przed wywiadem. W trakcie rozmowy zadawane są dwa rodzaje pytań: dotyczące tematu i osoby udzielającej wywiadu. Autorka przybliża zasady, którymi kierują się w trakcie przeprowadzania wywiadów tamtejsi historycy oralni, m.in. należy poinformować narratora o tym, jak będzie wyglądał wywiad i do czego posłuży, dać narratorowi czas do przygotowania się do wywiadu, uważać na formę, w jakiej zadaje się pytania, wybrać odpowiednie miejsce, dawać narratorowi poczucie, że jesteśmy bardzo zainteresowani jego relacją; nie należy również niepotrzebnie przerywać narratorowi, lecz dać mu w miarę samodzielnie prowadzić tok opowieści, dopóki nie zbacza zbytnio w nadmiernie oddalone rewiry. Z tekstu dowiadujemy się również o tym, w jaki sposób przeprowadza się transkrypcję. Tamtejsi praktycy historii mówionej stosują np. rozwikłanie skomplikowanych zdań, wycięcie rzeczy niemających nic wspólnego z narracją, umieszczanie historii dodanych później, po namyśle tam, gdzie powinny się oryginalnie znaleźć. Na początku transkrypcji relacji należy również zamieścić notatkę o narratorze ${ }^{51}$.

W artykule znajdziemy również informacje na temat sposobów postępowania z nagraniami wywiadów. Fragmenty nagrań są powierzchownie edytowane i włączane do dokumentacji z myślą o dokonaniu szczegółowej edycji później - w wypadku otrzymania zgody od relatora oraz gdy dźwięk na taśmie jest dobrej jakości, a głos narratora dobrze słyszalny oraz gdy nagranie dotyczy „materii ogólnego zainteresowania” ${ }^{2}$.

Bardzo interesująco kończy się artykuł Corinne Lathrop Gilb: „Historia mówiona nie może uchwycić przeszłości taką, jaką naprawdę była, a jedynie

49 Patrz: tamże, s. 8-10; M. Kurkowska, Archiwa pamięci-oral history, Historyka, t. 28, 1998, s. 68 .

50 C. Lathrop Gilb, dz. cyt., s. 338.

51 Tamże, s. 339-343.

52 Tamże, s. 344. 
taką, jaką jest widziana oczami teraźniejszości. [...] Lecz jeśli [historycy zajmujący się historią mówioną] wykonają swe zadanie dobrze, ich wywiady dadzą innym uczonym wskazówki, pomysły i oglądy, których w innym wypadku mogli by nigdy nie uzyskać; a pewnego dnia ich wywiady [...] powinny pomóc rozjaśnić przyszłym pokoleniom wartości i emocje, konflikty, obawy i dokonania tego zakątka współczesnego świata”53.

Kolejny artykuł to tekst pt. „Truman and the Presidency - Records and Oral Recollections” („Truman i prezydentura - dokumentacja i ustne wspomnienia”) z roku 1965, autorstwa Charlesa T. Morrisseya ${ }^{54}$. Autor (niegdyś historyk zajmujący się historią mówioną w Bibliotece Prezydenckiej Harry'ego S. Trumana) pracował nad projektem oral history dla Biblioteki Prezydenckiej Johna F. Kennedy'ego.

W tekście autor w dużej mierze skupia się na relacjach zachodzących między historią mówioną a dokumentacją "tradycyjną”, pisaną. O swoim podejściu mówi tak: „Ani dokumenty pisane, ani wspomnienia, nie są tak bogate $\mathrm{w}$ informacje i pewne, jak byśmy tego chcieli. Krytycy oral history, z jednej strony, mają tendencję do bagatelizowania fragmentaryczności dokumentów pisanych oraz tego, jak przydatne mogą być wywiady w uzupełnianiu badania dokumentacji. Obrońcy oral history, z drugiej strony, mają tendencję do przeceniania wartości dowodu zawartego w ustnych wspomnieniach oraz do lekceważenia wartości gruntownego badania źródeł pierwotnych. [...] Proponuję, aby więcej uwagi skupić na relacjach pomiędzy dokumentacją i wspomnieniami. Może być to pomocne dla wielu osób zainteresowanych rozpoczynaniem nowych projektów historii mówionej"55.

Autor również martwi się panującym powszechnie przekonaniem, że wspomnienia wyprą dokumenty pisane i odbiorą im rolę głównego środka dokumentującego przeszłość, z czym jednak sam się nie zgadza ${ }^{56}$. Dalsza część tekstu również poświęcona jest zagadnieniu relacji oral history i dokumentów pisanych. Morrissey uważa, że należy dobrze znać zasób aktowy, żeby dzięki historii mówionej uzupełnić w nim braki ${ }^{57}$. Zwraca uwagę na

53 Tamże.

54 Ch.T. Morrissey, Truman and the Presidency - Records and Oral Recollections, American Archivist, January 1965, Vol. 28, No. 1, s. 53-61.

55 Tamże, s. 54.

56 Tamże.

57 Tamże, s. 55-56. 
to, że dokumenty pisane są najlepszym narzędziem oceniania wartości wspomnieńn ${ }^{58}$, a bieżące zapisy dotyczące wydarzeń mogą być dla historyka bardziej wiarygodne od wspomnień czynionych po czasie ${ }^{59}$.

Charles T. Morrissey podkreśla, że dobrą praktyką związaną z przygotowaniem się do wywiadu (w tym z zapoznaniem się z istniejącą dokumentacją pisaną) jest przejrzenie dokumentacji osoby, która nas interesuje jako ewentualny narrator; pomoże to również w transkrybowaniu wywiadu. Tym sposobem dokumentacja i wspomnienia jednej osoby mogą być dostępne w jednym miejscu, co byłoby ułatwieniem dla uczonych ${ }^{60}$.

Autor wspomina o potrzebie specjalizacji; z jego doświadczenia w Truman Library wynika, że często bardzo ważne osobistości nie pamiętają istotnych wydarzeń tak dobrze, jak pamiętają je mniej rozpoznawani gracze sceny politycznej; tym samym wywiady z mniej znaczącym osobami na konkretne tematy mogą mieć większą wartość niż rozmowa z bardzo poważaną osobistością na bardzo szeroki wachlarz tematów ${ }^{61}$.

W artykule autor zwraca uwagę na fakt, że w literaturze wielokrotnie wspomina się o tym, jak ważne jest dokładne przygotowanie się przed każdym wywiadem; jednocześnie podejrzewa, że hołd takim studiom wstępnym składany jest przede wszystkim w teorii, natomiast w mniejszym stopniu realnie, w praktyce ${ }^{62}$.

Kolejnym zagadnieniem poruszonym $\mathrm{w}$ tekście są trudności, z którymi mogą spotkać się osoby przeprowadzające wywiady. Jednym z nich jest sytuacja, gdy problemy lub praca narratorów były bardzo skomplikowane i trudne, dlatego teraz ludzie ci nie mogą sobie ich przypomnieć. Czasem zdarza się również tak, że narratorzy nie chcą ujawniać swoich wspomnień, bo są one dla nich zbyt osobiste ${ }^{63}$. Wspomnienia mogą niekiedy uprościć i rozwikłać niektóre kwestie; czasem jednak jest wręcz przeciwnie - więcej wspomnień powoduje powstanie większej liczby wersji wydarzeń i ich skomplikowanie $^{64}$. Autor sądzi, że nowe projekty historii mówionej będą wciąż spotykać

\footnotetext{
58 Tamże, s. 56.

59 Tamże, s. 55.

60 Tamże, s. 56-57.

61 Tamże, s. 57.

62 Tamże, s. 56.

63 Tamże, s. 57.

64 Tamże, s. 60.
} 
się z tymi problemami, z którymi spotykały się poprzednie. Z pomocą może przyjść zwrócenie większej uwagi na relacje dokumentów pisanych ze wspomnieniami ${ }^{65}$.

Kolejnym tekstem o historii mówionej wydrukowanym przez Stowarzyszenie Archiwistów Amerykańskich (również w numerze styczniowym roku 1965) jest „Problems for Practicioners of Oral history” („Problemy praktyków oral history") autorstwa Donalda C. Swaina ${ }^{66}$.

Uczony niemało miejsca poświęca zagadnieniu stosunku historyków do historii mówionej; zarówno obecnego ich nastawienia, jak i tego, jak w przyszłości relacje te powinny wyglądać oraz w jakich celach praktycy historii mogą używać wywiadów. Autor sądzi, że historycy nie doceniają oral history z powodu ogólnego przekonania o małej wartości dowodu mówionego ${ }^{67}$. Powstawanie coraz to nowych inicjatyw historii mówionej jest zaletą z punktu widzenia historyków i archiwistów. Autor wyraża jednak pogląd, że nie powinno się już skupiać na tworzeniu kolejnych projektów. Historycy powinni nauczyć się wykorzystywania materiałów dostępnych dzięki projektom oral history oraz być gotowymi do stania się historykami oralnymi ${ }^{68}$. Historycy nie powinni pomijać relacji historii mówionej jako źródeł do swoich badań; jednocześnie autor artykułu zaznacza, że zbiory oral history zawierają zarówno wartościowe wspomnienia, jak i pewną liczbę bezużytecznych fantazji ${ }^{69}$. Historycy powinni zwracać się w kierunku historii mówionej zwłaszcza w przypadku, gdy potrzebne im do badań dokumenty pisane są tajne i z tego powodu nieudostępniane ${ }^{70}$.

Następnie autor prezentuje swoje główne obserwacje poczynione w trakcie trzyletniej pracy w projektach historii mówionej. Zaznacza, że metoda ta jest wyjątkowo kosztowna i czasochłonna, zwłaszcza w przypadku, gdy nagrywa się wywiad na taśmę. Podaje nawet miażdżące liczby: jedna godzina wywiadu jest efektem czterdziestu godzin pracy (w tym: przygotowanie do wywiadu, podróż, wywiad, transkrybowanie, edytowanie) ${ }^{71}$. W związku z tym Swain

65 Tamże, s. 60-61.

66 D.C. Swain, Problems for Practitioners of Oral history, American Archivist, January 1965 , Vol. 28, No. 1, s. 63-69.

67 Tamże, s. 63.

68 Tamże, s. 64.

69 Tamże.

70 Tamże, s. 64-65.

71 Tamże, s. 65. 
pisze, że nie zawsze warto używać urządzenia nagrywającego dźwięk. Uważa, że narratorzy są bardziej skrępowani, gdy ich wypowiedzi są rejestrowane. Ponadto często chcą znacząco poprawiać transkrypcję, ponieważ inaczej odbiera się słowo zapisane, a inaczej się je wypowiada. Dodaje również, że nie bez znaczenia są względy praktyczne: magnetofon jest ciężki, trzeba go ze sobą bezustannie nosić, a niekiedy psuje się i nastręcza dodatkowych trudności ${ }^{72}$. W związku z tym Donald C. Swain uważa, że do zapisania danych historycznych ujawnianych w trakcie wywiadu wystarczą notatki robione w trakcie lub tuż po nim ${ }^{73}$. Taki sposób zapisywania danych jest również mniej czasochłonny, podobnie jak inna metoda proponowana przez autora artykułu, mianowicie zwięzła, skupiona na konkretach konwersacja ze świadkiem zamiast długiego, pogłębianego wywiadu ${ }^{74}$.

Swain zauważa jednak również, że sukces wywiadu oral history zależy od statusu świadka historii. Z jego doświadczeń wynika, że najlepsze relacje pochodzą od osób niezbyt dobrze znanych, ale będących blisko ważnych wydarzeń, takich jak osobiści asystenci, sekretarki, złote rączki ${ }^{75}$.

Autor dostrzega i opisuje także ograniczenia oral history. Ludzie mają tendencję do zapominania, czasem na przykład zapominają o ważnych szczegółach w trakcie udzielania wywiadu, choć wcześniej dobrze o nich pamiętali. Niekiedy ubarwiają swą opowieść i zwiększają rolę, jaką odegrali w opisywanych wydarzeniach. Według Swaina oral history daje nie tyle szczegółową, nową wiedzę o jakichś wydarzeniach, co nieuchwytną „emfazę” („znaczenie o względnej ważności nadane pewnym sprawom przez jej uczestników”) i atmosferę danej epoki, subiektywne odczucie danej osoby lub czasu' ${ }^{76}$. Autor kończy swój artykuł stwierdzeniem, że amerykańscy historycy i archiwiści powinni poświęcać oral history więcej uwagi; kluczem do odpowiedniego użycia historii mówionej jest pamiętanie o tym, że jest to „suplement, a nie substytut dokumentów pisanych" (słowa Charlesa T. Morrisseya) ${ }^{77}$.

Styczniowy numer z roku 1965 niesie ze sobą jeszcze dwa artykuły o historii mówionej. Jednym z nich jest tekst autorstwa Saula Benisona: „Reflections

\footnotetext{
Tamże, s. 65-66.

Tamże, s. 66.

74 Tamże, s. 66-67.

75 Tamże, s. 67-68.

76 Tamże, s. 68.

77 Tamże, s. 69.
} 
on oral history” („Refleksje o oral history”) ${ }^{78}$. Celem artykułu jest przybliżenie, do czego służy historia mówiona; jest on również komentarzem do artykułów Morrisseya i Swaina zamieszczonych w tym samym numerze „American Archivist", a omówionych powyżej ${ }^{79}$.

Autor zwraca uwagę na to, że powstaje coraz więcej dokumentacji. Przytacza zdanie niektórych historyków, że technologia, która odpowiada za taki przyrost źródeł, paradoksalnie pozbawia historyka różnorodności i detali, będących właściwymi dla przebiegu zdarzeń. Przywołuje też wypowiedź Louisa Starra, dyrektora Columbia University Oral history Research Office, że samochód, samolot i telefon są odpowiedzialne za to, że ludzie nie piszą tak wielu listów jak poprzednie generacje. Autor jednak osobiście wątpi, aby nowoczesne metody komunikacji wyeliminowały z obiegu list prywatny czy prywatne dokumenty; jako przykłady podaje osoby, z którymi przeprowadzał wywiady, które miały w swoich domach dziesiątki tysięcy zachowanych prywatnych listów ${ }^{80}$. Następnie Benison pisze: „Stary historyczny aforyzm, że »bez dokumentów nie ma historii« dotyczy również oral history. Odkrycie i używanie tych dokumentów jest w zasadzie jedną z funkcji historii mówionej”"1.

Następnie Saul Benison przytacza techniki pracy historyków oralnych. Według niego historyk musi zapoznać się z istniejącymi źródłami pierwotnymi i wtórnymi, aby dostrzec historyczne relacje i zdefiniować historyczne problemy. Uzbrojony w magnetofon, musi pobudzić pamięć o przeszłości świadka historii. Musi zebrać od niego współczesną dokumentację, aby poddać próbie kruchość ludzkiej pamięci i uzupełnić świadectwo. Powinien również wesprzeć narratora w końcowym przygotowywaniu wspomnienia, aby powiedziało ono to, co chce przekazać narrator ${ }^{82}$. Tak powstałe wywiady zawierają nie tylko informacje na temat narratora i osób z nim związanych, ale również na temat klimatu i atmosfery wydarzeñ ${ }^{83}$.

Według Benisona autobiografia powstała w wyniku zastosowania metody oral history jest nowym rodzajem dokumentu historycznego; jest on współtworzony przez świadka historii oraz historyka - owocuje to zarówno jego

${ }^{78}$ S. Benison, Reflections on oral history, American Archivist, January 1965, Vol. 28, No. 1, s. 71-77.

79 Tamże, s. 71.

80 Tamże, s. 72.

81 Tamże.

82 Tamże, s. 72-73.

83 Tamże, s. 73. 
słabościami, jak i mocnymi stronami ${ }^{84}$. Autor uważa, że relacja oral history nie jest jedynie uzupełnieniem czy dodatkiem do już istniejących źródeł; jest próbą pierwszej interpretacji wydarzeń historycznych oraz uporządkowania źródeł istotnych w kontekście życia konkretnego człowieka ${ }^{85}$.

Saul Benison podkreśla również, że historyk oralny musi być szczegółowy w swoich badaniach i działaniach, musi być pewien, że przekaże przyszłemu historykowi korzystającemu z danego świadectwa, z jakimi materiałami pracował, przygotowując się do wywiadu oraz jakie były jego założenia filozoficzne i historyczne. Tym samym relacje oral history powinny zawierać pytania zadawane przez przeprowadzającego wywiad oraz bibliografię źródeł pierwotnych i wtórnych użytych przez niego. Niektórzy historycy są niedokładni, nie włączają do relacji swoich pytań, nie tworzą bibliografii, nie mierzą się z problemami historycznymi - z powodów finansowych i ekonomicznych ${ }^{86}$.

W swoim tekście Benison odnosi się do problemu krótkich wywiadów poruszonego przez Swaina ${ }^{87}$; autor jest zwolennikiem długich i wyczerpujących wywiadów, dostrzega jednak pozytywy płynące z krótkich, konkretnych relacji, zwłaszcza dla badania szczegółowo postawionych problemów historycznych; są one użyteczne przede wszystkim dla tego, kto je przeprowadza, mniej jednak dla przyszłych pokoleń historyków ${ }^{88}$.

Saul Benison odnosi się również do sugestii Morrisseya, aby przeprowadzać wywiady z mniej znanymi osobami ${ }^{89}$. Nie tylko wybitne osobistości mają wspomnienia istotne w swej treści dla historyków. Autor namawia do nagrywania tradycji ustnej ludów niepiśmiennych, uważa on bowiem, że paradoksalnie umyka ona historykom oral history. Za grupy warte nagrania poczytuje on np. imigrantów, robotników, Murzynów ${ }^{90}$.

Autor uważa, że zachowywanie tylko transkrypcji, a niszczenie nagrania głosu narratora jest szkodliwe. Według niego zanika wtedy część znaczenia słów (przekazywana np. przez modulację głosu) oraz dodatkowe informacje o narratorze. Benison postuluje, aby bez względu na koszty zachowywać całe

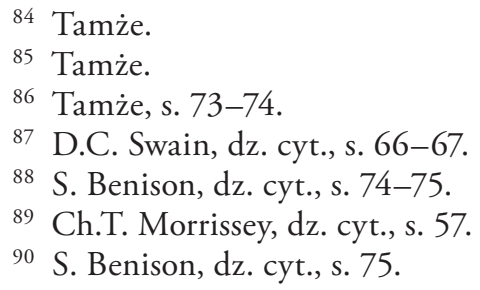


nagranie wywiadu ${ }^{91}$. Proponuje nawet, aby historycy nagrywali współczesny im krajobraz dźwiękowy jako integralną część naszego środowiska, zarówno społecznego, jak i fizycznego ${ }^{92}$.

W swym artykule Saul Benison zwraca również uwagę na walory oral history w edukacji ${ }^{93}$. Jednocześnie zdaje sobie sprawę z tego, że jego spostrzeżenia są bardzo nowoczesne i perfekcjonistyczne; pod koniec pisze: „Być może moje wyobrażenia [przewidywania] są mrzonką" ${ }^{94}$.

Ostatnim artykułem z tego numeru „American Archivist” (January 1965, Vol. 28, No. 1), który omówię, jest tekst Goulda P. Colmana pt. „Oral History - An Appeal for More Systematic Procedures” („Oral history - apel o bardziej systematyczne metody") ${ }^{95}$.

Autor rozpoczyna artykuł od zagadnienia, czym jest oral history. Uważa bowiem, że powstają coraz to nowe tego typu inicjatywy, na uniwersytetach i w bibliotekach prezydenckich, brak jednak wciąż zgody co do tego, czym właściwie jest historia mówiona ${ }^{96}$. Spotkanie Mississippi Valley Historical Association pokazało, jak różnie rozumie się ten termin: od robiącego notatki historyka rozmawiającego ze świadkiem historii w celu przeprowadzenia własnych badań do dosłownego zapisu wywiadu (również dla własnych celów) ${ }^{97}$. Co do własnego rozumienia historii mówionej Colman pisze tak: „Jako że oral history jest teraz częścią naszego języka, wydaje się wskazanym wyjaśnić jego znaczenie poprzez ograniczenie użycia go do przypadków, w których nagranie na taśmie jest przetranskrybowane i udostępnione innym badaczom"98.

Według Goulda P. Colmana głównym problemem oral history jest to, że do powstania produktu finalnego przykładają się trzy osoby: osoba przeprowadzająca wywiad, narrator i osoba pisząca transkrypcję. Gdy badacze odkryją, że zarówno nagranie, jak i transkrypcja nie oddają w pełni rzeczywiście przeprowadzonego wywiadu, mogą oni zwątpić w integralność procedur oral

91 Tamże, s. 76.

92 Tamże.

93 Tamże.

94 Tamże, s. 77; w oryg. "Perhaps what I have envisioned is a pipedream".

95 G.P. Colman, Oral History - An Appeal for More Systematic Procedures, American Archivist, January 1965, Vol. 28, No. 1, s. 79-83.

96 Tamże, s. 79.

97 Tamże, s. 79-80.

98 Tamże, s. 80 . 
history. Rozwiązaniem jest ustalenie pewnych zasad postępowania w ramach tej metody, aby można było odróżnić, kto jaki wkład wniósł do danej relacji ${ }^{99}$.

Autor sądzi, że to „przeprowadzający wywiad musi przejąć odpowiedzialność za to, aby nagranie oddawało to, co działo się w trakcie wywiadu” ${ }^{100}$. Ponadto na nagraniu powinny być zaznaczone miejsca, kiedy magnetofon był wyłączony ${ }^{101}$. Osoba transkrybująca relację powinna dokonać tej transkrypcji w taki sposób, aby oddawała ona to, co zostało nagrane na taśmę. Colman uważa również, że osoby tworzące transkrypcję dokonują zbyt wielu poprawek w tekście wywiadu ${ }^{102}$.

Badacz odnosi się także do relacji transkryptu i wywiadu: „część wywiadu zaginie w transkrypcji [...] najlepszym, co można zrobić, to informować każdego udzielającego wywiadu, że do niego należy decyzja czy taśma ma zostać zachowana i, jeśli tak, pod jakimi warunkami może być używana"103.

Autor artykułu mówi też o relacjach respondenta z przeprowadzającym wywiad, o tym, że według niego wpływają one w pewnym stopniu na treść wywiadu ${ }^{104}$.

W dalszej części tekstu Colman odnosi się do postulatu Saula Benisona, stanowiącego, aby załączać do wywiadu bibliografię źródeł, z których korzystał historyk, przygotowując się do wywiadu ${ }^{105}$. Colman uważa, że jest to nieetyczne, ponieważ na kształt tej bibliografii nie ma wpływu respondent, podczas gdy powinien mieć wpływ na treść całości swojego wywiadu ${ }^{106}$.

Następny artykuł o historii mówionej opublikowany w „American Archivist” przypada na rok 1969. Jest to tekst autorstwa Amelii R. Fry i Willi Baum o tytule „A Janus Look at Oral history” („Janusowe spojrzenie na oral history") ${ }^{107}$. Janus to rzymski bóg o dwóch twarzach, a tytułowe janusowe spojrzenie na historię mówioną bierze się z tego, że autorki mają dwa odmienne doświadczenia $\mathrm{z}$ oral history - jedna $\mathrm{z}$ autorek była edytorem i przeprowadzała wywiady, a druga była dyrektorem projektu oral history w Berkeley.

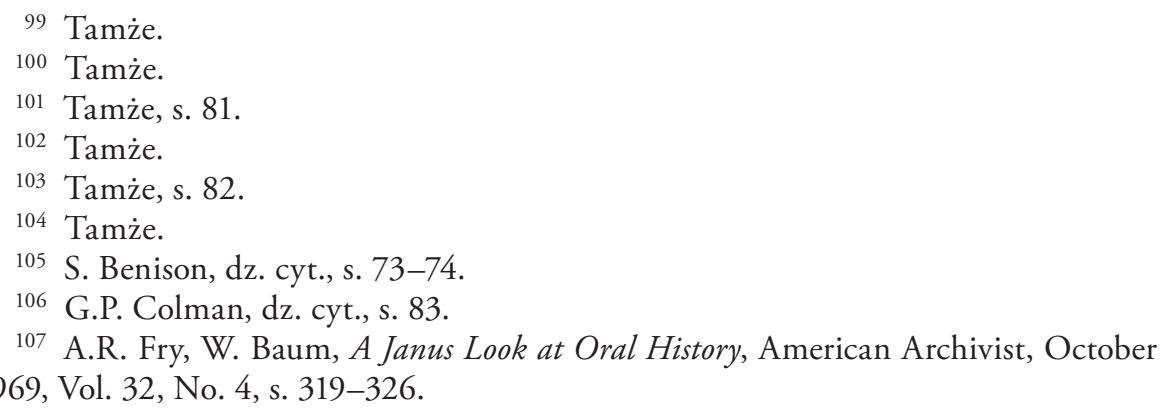


Od roku 1966 odbyły się trzy kolokwia dot. oral history, na rok 1969 przypada czwarte; z tej okazji autorki omawiają dotychczasową historię ruchu. Krótko wspominają początki oral history: Alana Nevinsa na Columbia University, Bancroft Library of the University of California, a także działalność Departamentu Obrony (seria wywiadów w wojsku) ${ }^{108}$. Autorki przywołują programy oral history związane z historią medycyny, a także przedstawiają szeroki wachlarz różnorodnych projektów dot. historii pracy, komputeryzacji, czarnej historii czy prezydentów Stanów Zjednoczonych ${ }^{109}$.

W roku 1966 po raz pierwszy odbyło się kolokwium dotyczące oral history, było ono okazją do spotkania praktyków tej metody. Zostało zorganizowane przez University of California, Los Angeles Oral history Office i odbyło się w Lake Arrowhead w Kalifornii. W tym czasie James V. Mink z UCLA i Louis Starr z Columbia University stworzyli struktury Oral History Association ${ }^{110}$. W trakcie pierwszego kolokwium podkreślono, jak bardzo ten nowy fach, jakim jest historyk oralny, jest obecnie potrzebny. Zadeklarowano, że tylko taki specjalista, zaopatrzony w magnetofon, może zapewnić archiwistom pewien ogląd przeszłości, w innym wypadku dość smętny ${ }^{11}$. Na pierwszym kolokwium oral history poruszono temat dotykany również w przytoczonych przeze mnie powyżej tekstach, mianowicie wpływu nowoczesnych (na tamte czasy) technologii na obecność i kształt źródeł historycznych. Uczestnicy spotkania zauważyli, że dwudziestowieczny człowiek, niestety, nie pisze już tak często pamiętników, a decyzje są podejmowane i rozmowy biznesowe prowadzone przez telefon lub podczas osobistych spotkań, które odbywają się dzięki przelotom samolotami odrzutowymi, nawet na duże odległości ${ }^{112}$.

Drugie kolokwium dot. historii mówionej odbyło się na Columbia University w 1967 roku. W jego trakcie oficjalnie przyjęto organizację Oral History Association, a Louis Starr został wybrany na jej pierwszego prezydenta ${ }^{113}$. Zebrani zastanawiali się m.in. nad tym, kim jest historyk oralny ${ }^{114}$. Ponadto „Po raz kolejny już dyskutowano definicję oral history. [...] Inny cytowali

\footnotetext{
108 Tamże, s. 319.

109 Tamże, s. 320.

110 Tamże.
}

111 W oryg. "only the oral historian, with his trusty tape recorder, could restore the otherwise bleak outlook for the archivist”; tamże, s. 321.

112 Tamże.

113 Tamże.

114 Tamże. 
Philipa Brooksa z Truman Library: "Historia mówiona powinna być historią i powinna być mówiona«. Ale gdy burza mózgów dobiegła końca, okazało się, że wszystko co mówi, śpiewa i gdacze do mikrofonu może zasługiwać na termin »oral history«. Wszyscy powrócili do swych instytucji z niepokojącym pytaniem w głowach, dotyczącym natury grupy, za przynależność do której zapłacili siedem i pół dolara"115.

Trzecie kolokwium odbyło się w 1968 roku w Nebraska Conference Center. W jego trakcie uznano, że Brooksjańska definicja oral history może okazać się wystarczająca. Obecni formalnie stwierdzili, że oral history jest „metodą zbierania korpusu informacji historycznych w formie oralnej, zazwyczaj na taśmie"116.

Kodeks etyczny nazywany „Goals and Guidelines” („Cele i wskazówki”) autorstwa Oscara Winthera z Indiana University, Jamesa Harveya Younga z Emory University, Philipa C. Brooksa z the Harry S. Truman Library w Independence w Missouri i Amelii Fry z University of California, Berkeley jednogłośnie przyjęto 25 listopada ${ }^{117}$. Odezwa ta podzielona została na trzy główne części: wskazówki dla udzielającego wywiadu, wskazówki dla przeprowadzającego wywiad i wskazówki dla instytucji sponsorujących.

Pierwsza część zawierała następujące postulaty: należy spełniać życzenia narratora co do kształtu wywiadu; należy dokładnie mu wytłumaczyć wszelkie zagadnienia prawne związane z udzielaniem relacji oral history; świadek powinien mieć m.in. prawo do edycji transkryptu i zdecydowania, czy nagranie ma być zniszczone, czy udostępnione; narrator musi w pełni zrozumieć cele projektu, aby znając związane z nim koszty i wysiłki, przekazać użyteczne informacje dotyczące badanego tematu ${ }^{118}$.

Zgodnie z częścią drugą, przeprowadzający wywiad powinien zbierać wywiady dla szerszego grona badaczy, a nie tylko dla siebie; aby wywiad był jak najbardziej wartościowym źródłem historycznym, powinien on najpierw zapoznać się z doświadczeniami narratora i jeśli to możliwe - przejrzeć dokumentację narratora przed przeprowadzeniem wywiadu, dzięki temu w trakcie wywiadu będzie można uczestniczyć w procesie przywoływania wspomnień;

115 Tamże, s. 322.

116 Tamże.

117 Tamże.

118 Tamże, s. 322-323. 
ponadto wywiady powinny być przeprowadzane $\mathrm{w}$ duchu obiektywności i naukowej integralności ${ }^{119}$.

Część trzecia zawiera wskazówki dla instytucji sponsorujących: powinny one przygotować łatwe w użytku taśmy lub dokładnie spisane transkrypcje; zapisy oral history powinny być dostępne społeczności akademickiej, a przepisy rządzące ich używaniem powinny być przedstawione w sposób jasny ${ }^{120}$.

Poza problemami przedstawionymi w kodeksie etycznym historii mówionej autorki artykułu zauważają jeszcze inne warte przedyskutowania kwestie związane z oral history. Za ważne zagadnienie uważają ułatwienie wykorzystania oral history przez społeczność badaczy; do tej pory transkrypty i taśmy były bowiem pilnie strzeżone, a dotarcie do nich wiązało się z dużym wysiłkiem $^{121}$. Należy udostępnić społeczności akademickiej informacje nt. tytułów i lokalizacji materiałów oral history. Oral History Association nie ma jednak możliwości stworzenia takiego katalogu; według autorek rozwiązaniem jest traktowanie historii mówionej jak innych materiałów historycznych i włączenie ich do National Union Catalog of Manuscript Collections ${ }^{122}$.

Fry i Baum widzą również inne jeszcze problemy i pytania związane z oral history, np. zagadnienie, kto powinien edytować transkrypt wywiadu i w jakim stopniu. Nie mniej istotna jest kwestia zachowywania lub usuwania nagrań, w różnych inicjatywach rozwiązywana na różne sposoby. Jedni uważają nagranie za źródło pierwotne, a transkrypcję za wtórne i zakazują jego usuwania. Inni uważają, że należy zachować tylko taśmy osób najważniejszych dla historii. Wiele projektów zachowuje tylko fragmenty relacji, a usuwa ich pozostałe części. Za kolejne ważne kwestie autorki uważają sprawę finansowania inicjatyw oral history oraz to, jak powinni być kształceni oralni historycy ${ }^{123}$.

Kolejny tekst o tematyce historii mówionej zaprezentowany w „American Archivist” pochodzi z roku 1973. Nie jest to jednak artykuł naukowy, a raczej forma raportu: „Oral History and Archivists: Some Questions to Ask, by the Committee on Oral History of the Society of American Archivists” („oral history I archiwiści: pytania, autorstwa Komitetu ds. Oral History Stowarzy-

\footnotetext{
119 Tamże, s. 323.

120 Tamże.

121 Tamże, s. 324.

122 Tamże.

123 Tamże, s. 325.
} 
szenia Archiwistów Amerykańskich") ${ }^{124}$. Raport ten zaprezentowany został przez przewodniczącego komitetu, Johna F. Stewarta. W przypisie zaprasza się czytelników do wysyłania komentarzy w związku z niniejszym tekstem, adresowanych do Stewarta lub do redakcji czasopisma. Na początku tekstu autor podkreśla, że oral history przeistoczyła się w zaakceptowaną, często stosowaną, ustaloną już praktykę, dlatego też należy spojrzeć na nowe problemy i potencjał tej techniki. Celem raportu jest stymulowanie do dyskusji nad historią mówioną, dlatego raport ten, wbrew swej nazwie, zadaje pytania, a nie daje odpowiedzi ${ }^{125}$.

Tak więc najpierw raport pyta o kwestie związane z personelem: czy są podstawy do tego, aby powstała profesja historyka oralnego (historyka zajmującego się historią mówioną), czy należy po prostu uznać oral history za jedną z metod używaną przez osoby zajmujące się zbieraniem i zachowywaniem świadectw historii? ${ }^{126}$

Następnie komitet stawia problemy związane z organizacjami zajmującymi się tą sferą działalności. Czy powinno się organizacyjnie oddzielać funkcję przeprowadzania wywiadów od funkcji administrowania ich użyciem w badaniach? W jakich wypadkach i czy w ogóle powinno się organizować całkowicie niezależne programy oral history (niezależne od żadnej organizacji lub działające w ramach dużych, wielozadaniowych instytucji, jak uniwersytety, firmy, agencje rządowe czy fundacje)? Czy programy historii mówionej muszą zawsze wiązać się z organizacjami o charakterze historycznym (archiwa$\mathrm{mi}$, stowarzyszeniami historycznymi)? ${ }^{127}$

Ponadto jaka powinna być rola $\mathrm{w}$ ruchu oral history dwóch organizacji najbardziej zainteresowanych historią mówioną: OHA (Oral History Association, Towarzystwo Historii Mówionej, funkcjonujące w Stanach Zjednoczonych) i SAA (Society of American Archivists, Stowarzyszenie Archiwistów Amerykańskich)? ${ }^{128}$

W ramach prac nad raportem komitet zbadał również status oral history w ramach archiwistyki; przeprowadzono ankietę, z której wynika, że 20\%

124 [b.a.], Oral History and Archivists: Some Questions to Ask, by the Committee on Oral History of the Society of American Archivists, American Archivist, July 1973, Vol. 36, No. 3, s. 361-365.

125 Tamże, s. 361.

126 Tamże, s. 362.

127 Tamże.

128 Tamże. 
członków SAA w jakiś sposób zaangażowało się w oral history. Spośród nich tylko 20\% przeprowadzało wywiady; większość była dyrektorami projektu lub kuratorami zbiorów ${ }^{129}$. $73 \%$ ankietowanych uważa, że oral history powinna być uważana za część działalności archiwalnej. Duży procent generalnie ufa wierności wspomnień zawartych w wywiadach oral history, a niewielu zapytanych sądzi, że oral history to chwilowa, przemijająca moda ${ }^{130}$.

Raport porusza również kwestię wyszukiwania i użytkowania oral history. Wymienia on trzy poziomy użytkownika: użytkownik szukający instytucji specjalizujących się w danym temacie oraz kolekcji wywiadów odnoszących się do konkretnego tematu; użytkownik szukający konkretnych wywiadów wewnątrz instytucji i kolekcji; użytkownik szukający konkretnych informacji w ramach danego wywiadu ${ }^{131}$. Te trzy poziomy użytkowników są jednocześnie poziomami poszukiwań odbywających się w ramach pracy nad historią mówioną; są to: lokalizowanie kolekcji, lokalizowanie wywiadów i lokalizowanie fragmentów wywiadu. Wszystkie te poziomy poszukiwań zostały zanalizowane przez członków komitetu, czego efektem są pytania ich dotyczące.

Co do lokalizowania kolekcji: czy system National Union Catalog of Manuscript Collections jest odpowiedni dla relacji oral history, czy potrzebny jest osobny przewodnik po zbiorach oral history w Ameryce? W jakim stopniu niedostateczne użycie historii mówionej spowodowane jest tym, że uczeni nie są w stanie odnaleźć kolekcji relacji dotyczących swojego tematu badawczego, a w jakim stopniu tym, że wątpią w metodę oral history? ${ }^{132}$

Co do lokalizowania wywiadów: jak wielkim wyzwaniem byłoby zintegrowanie pomocy informacyjno-wyszukiwawczych dla oral history z tymi dla manuskryptów/dokumentów? Raport wystosowuje nawet propozycje pomocy informacyjnych na poziomie kolekcji oral history: A) wyczerpująca nazwa i szczegółowy indeks rzeczowy, B) zintegrowana lista ogólnych tematów poruszonych w wywiadach, C) katalog transkrypcji wg nazwiska udzielającego wywiad, ogólnego tematu i numeru katalogowego, wraz z narracyjnym opisem zawartości i informacjami biograficznymi o udzielającym wywiadu ${ }^{133}$.

\footnotetext{
129 Tamże, s. 362-363.

130 Tamże, s. 363.

131 Tamże.

132 Tamże.

133 Tamże.
} 
Co do lokalizowania fragmentów wywiadu: czy do transkryptów powinny być dołączane szczegółowe indeksy, czy ogólny spis treści relacji nie byłby wystarczający? ${ }^{134}$

W tekście poruszono również kwestię użycia wywiadów oral history przez badaczy, to, jak powinny służyć indywidualnym uczonym (czy są powody przeciwko wypożyczaniu kopii transkryptów pomiędzy bibliotekami? jak wygląda kwestia sporządzania kopii z transkryptów do użytku naukowego?) oraz ogólnie - społeczności akademickiej ${ }^{135}$. Autorzy dotykają również problemu kosztowności i czasochłonności metody oral history ${ }^{136}$. W związku z tym pytają „Czy indeksowanie nagrań i rejestry oral history są realnymi odpowiedziami na problem wysokich kosztów transkrypcji? ${ }^{137 ”}$.

Kolejny artykuł, który omówię, to tekst „The Archival Edge” F. Geralda $\mathrm{Hama}^{138}$. Nie jest to jednak artykuł o oral history. Tematem jego jest gromadzenie zasobu archiwalnego przez amerykańskich archiwistów - w tym kontekście w tekście pojawiają się odniesienia do historii mówionej.

Autor rozpoczyna artykuł od stwierdzenia, że zadaniem archiwistów, jednocześnie najważniejszym i najbardziej wymagającym intelektualnie, jest selekcja informacji, dzięki której w przyszłości będzie można zapoznać się z zapisami dotyczącymi ludzkich doświadczeń naszych czasów. Jednocześnie zauważa, że proces selekcji tych informacji jest przypadkowy, fragmentaryczny i nieskoordynowany. Autor uważa, że błędność procesu selekcji informacji jest powodem tendencyjności zasobu archiwalnego. Zasób skłania się ku rządowi, biznesowi i wojsku, podczas gdy części życia społecznego związane $\mathrm{z}$ biedą i niemające mocy decyzyjnej zostają odsunięte na bok ${ }^{139}$. Ham przypomina, jak niegdyś Gould P. Colman na łamach „American Archivist” zarzucał archiwom upolitycznienie - że jest nieproporcjonalnie dużo dokumentacji rządowej w stosunku do wkładu rządu np. w kulturę, a nieproporcjonalnie mało materiałów np. rodzinnych, a sama dokumentacja jest tendencyjna ${ }^{140}$. „Dokumentacja stawała się coraz bardziej stronnicza przez naszą

134 Tamże.

135 Tamże, s. 364.

136 Tamże, s. 364-365.

137 Tamże, s. 365.

138 F.G. Ham, The Archival Edge, American Archivist, January 1975, Vol. 38, No. 1, s. $5-13$.

139 Tamże, s. 5.

140 Tamże, s. 6. 
skłonność do gromadzenia tego, co jest najłatwiej dostępne i poprzez ograniczanie źródeł oral history głównie do stosunkowo dobrze udokumentowanych aspektów kultury [...]"141.

Ponadto autor zarzuca archiwom luki w dokumentowaniu nawet tych klasycznych pól tematycznych, czego wyrazem jest np. kompletny brak materiałów dotyczących piwowarstwa w Milwaukee, z którego miejscowość ta jest od dawna znana. F.G. Ham twierdzi również, że archiwiści marnują swój czas na gromadzenie materiałów o wątpliwej wartości ${ }^{142}$. Prawdziwym jednak problemem jest dla autora fakt, że społeczność archiwistów nie dostrzega błędów w procedurze gromadzenia zasobu archiwalnego ${ }^{143}$. Panuje przekonanie, że archiwista jest tylko kustoszem, strażnikiem zasobu archiwum, że nie jego zadaniem jest ocena tego, co warto zachować dla przyszłości, a czego nie; tak uważają również archiwiści. Co więcej, panuje tradycja, a wręcz obsesja spoglądania na zawód archiwisty wyłącznie ze strony praktycznej, jako na rzemieślnika ${ }^{144}$.

Ham sądzi, że archiwa poddają się modzie, jaka w danym momencie panuje na „rynku akademickim”. Powstają nowe archiwa do nowych, popularnych tematów: historia czarnoskórych, imigrantów, pomocy społecznej, architektury, popkultury, nauki; „nic dziwnego, że zasoby archiwów zbyt często odnoszą się do wąskich zainteresowań badawczych, zamiast do szerokiego spektrum ludzkiego doświadczenia"145.

Autor widzi rozwiązanie takiego stanu rzeczy. Aby wypełnić luki w dokumentacji, archiwista powinien stać się „reporterem swoich czasów”. Służące mu do tego narzędzia to tworzenie oral history, robienie zdjęć czy zbieranie danych w ankietach ${ }^{146}$. Ham postrzega jednak w tym miejscu oral history nie jako narzędzie do stworzenia drobiazgowo wyedytowanego źródła do pisanych tekstów o prezydentach, a raczej jako źródło na temat codziennych decyzji niższych rangą działaczy i życia zwykłych obywateli ${ }^{147}$.

\footnotetext{
141 Tamże.

142 Tamże.

143 Tamże, s. 7.

144 Tamże.

145 Tamże, s. 8.

146 Tamże, s. 9.

147 Tamże.
} 
Krótki komentarz do idei F.G. Hama daje Lester J. Cappon ${ }^{148}$. Wyśmiewa on wręcz idee Hama, aby archiwista stał się dostarczycielem źródeł do archiwum przez nagrywanie oral history, robienie fotografii i przeprowadzanie ankiet. Twierdzi, że są to metody bardzo drogie i kpi z przejścia archiwisty od roli zbieracza źródeł do roli ich twórcy ${ }^{149}$.

Kolejny artykuł to „Oral history and the Archives” („Oral history i archiwa”) Ronalda L. Filippellego z roku $1976^{150}$. Autor powołuje się na raport Komitetu ds. Oral history Stowarzyszenia Archiwistów Amerykańskich opublikowanego w „American Archivist” w lipcu 1973 r. i pragnie wziąć udział w debacie, którą raport starał się wywołać ${ }^{151}$. Filippelli uważa, że „[...] nasi bracia w historycznej profesji zdominowali arenę [dyskusji] swymi burzami dotyczącymi dowodowej wartości produktu procesu oral history. [...] Dla archiwistów istnieją bardziej konkretne problemy [...]"152. I to tymi właśnie konkretnymi, archiwalnymi zagadnieniami związanymi z historią mówioną zajmuje się w swym artykule Ronald Filippelli.

Autor uważa, że historia mówiona jest po prostu kolejnym typem dokumentacji, którym należy zająć się w archiwach i choć wymaga ona pewnych zmian w procesie zarządzania, to nie różni się znacząco od innych rodzajów materiałów archiwalnych (zwłaszcza w transkrypcie), niekiedy nawet łatwiej jest zarządzać oral history niż innymi rodzajami dokumentów ${ }^{153}$.

Filippelli daje negatywną odpowiedź na pytanie, czy istnieją podstawy do powołania profesji oralnego historyka [„oral historian”]. Uważa on, że historia mówiona jest tylko jedną z metod pozyskiwania materiałów do badań historycznych ${ }^{154}$.

Posługując się użyteczną w tym wypadku i pobudzającą wyobraźnię metaforą, autor wyjaśnia swoje spojrzenie na rolę archiwisty w tworzeniu relacji historii mówionej: „Lecz to, co jest najważniejsze dla archiwistów w procedurze oral history, to nie znawstwo archiwistyki, ale raczej znajomość przedmiotu

148 L.J. Cappon, The Archivist as Collector, American Archivist, October 1976, Vol. 39, No. 4, s. 429-435.

149 Tamże, s. 433.

150 R.L. Filippelli, Oral History and the Archives, American Archivist, October 1976, Vol. 39, No. 4, s. 479-483.

151 Tamże, s. 479.

152 Tamże.

153 Tamże.

154 Tamże. 
[...] Jeśli historyczny budynek ma zostać zburzony, dobry zmysł archiwalny domaga się wykonania fotograficznego uwiecznienia tej konstrukcji, nim tak się stanie. Teraz, rzecz jasna, ktokolwiek zajmujący się fotografią będzie musiał wiedzieć takie rzeczy, jak to, jak posługiwać się aparatem, jakiego użyć filmu, jak zrobić odpowiednie ujęcie. Tego można się łatwo nauczyć. To, czego tak łatwo nauczyć się nie da, to czy dany budynek jest lub nie jest historycznie czy architektonicznie znaczący, które detale są najważniejsze, które perspektywy są najbardziej użyteczne dla przyszłych badań i inne tego typu rzeczy, wiadome tylko historykowi architektury. Zadaniem archiwisty jest wiedzieć, które budynki mają być zniszczone oraz kto jest wykwalifikowany do dokonania oceny historycznej. Jeśli, oczywiście, zdarzy się, że archiwista jest też architektem, ze spokojnym sumieniem może to zrobić samodzielnie. Chodzi o to, że w oral history taka znajomość przedmiotu wymaga nacisku"155.

Ronald Filippelli zastanawia się również nad miejscem oral history w ramach działalności archiwalnej i pisze: „W większości [oral history] będzie robiona poza jakimikolwiek formalnymi organizacjami. Po fakcie często będzie trafiać do archiwów, jako rezultat projektu badawczego jakiegoś historyka. To jest $\mathrm{w}$ porządku, materiał ten powinien być oceniany wtedy jak każdy inny nabytek"156.

Autor powtarza zaproponowany w raporcie SAA podział użytkowników oral history na 3 poziomy (szukających instytucji lub kolekcji relacji zawierających informacje na pewien konkretny temat; szukających konkretnych relacji w ramach instytucji lub kolekcji; szukających konkretnych informacji w pojedynczym wywiadzie). Uważa, że są to te same grupy użytkowników, które występują w przypadku innych materiałów archiwalnych ${ }^{157}$. Filippelli w swym artykule odnosi się do sposobów informowania użytkowników o zasobie w odniesieniu do tych trzech poziomów poszukiwań. Co do pierwszych dwóch poziomów, to jest poszukiwania instytucji lub kolekcji oraz relacji w ich ramach, jako narzędzia wymienia m.in. National Union Catalog of Manuscript Collections, noty w czasopismach naukowych oraz publikowane katalogi, w przypadku drugiego typu użytkowników podaje jako źródło informacji również listy relacji publikowane w pismach branżowych. Do trzeciego, najgłębszego poziomu poszukiwań, czyli szukania informacji

155 Tamże, s. 480.

156 Tamże, s. 481.

157 Tamże, s. 481-482. 
w wywiadzie, autor odnosi się następująco: „Do tego powinniśmy zapewnić szczegółowy indeks rzeczowy i osobowy, a ponadto streszczenie głównych akcentów wywiadu"158.

Filippelli odnosi się również do kwestii udostępniania relacji. Według niego powinny być one dostępne przez wypożyczalnie międzybiblioteczne. Ponadto powinno się zapewniać zawsze najszerszy możliwy dostęp do wywiadów, zwłaszcza że narratorzy zazwyczaj chętnie zezwalają na swobodny dostęp do swoich relacji. Wypożyczający powinien jednak być zaznajomiony z wszelkimi zastrzeżeniami i warunkami korzystania z wywiadu ${ }^{159}$.

Autor porusza również kwestię, kiedy archiwa powinny angażować się w działalność oral history. Widzi on dwa takie przypadki. Po pierwsze wtedy, gdy posiadają na ten cel fundusze zewnętrzne, pochodzące np. z fundacji, stowarzyszeń zawodowych czy przedsiębiorstw. Po drugie wtedy, gdy w swoim zasobie posiadają fizyczną dokumentację do danego tematu: „Typ projektu, którego potrzebujecie, powinien organicznie wyrosnąć z rodzaju zasobów które już posiadacie lub których oczekujecie. Dokumentacja ta i wywiady będą się wzajemnie wspierać, zapewniając dla siebie nawzajem odpowiedzi, ujawniając wskazówki, sugerując nowe podejścia do organizacji, pomagając innymi sposobami w zbieraniu tych drugich"160.

Kolejnym wartym omówienia w tym miejscu artykułem jest tekst Williama W. Mossa pt. „Oral History: An Appreciation” („Oral history: uznanie") ${ }^{161}$. Uczony ten w tym miejscu zajmuje się dokładnie tym, na co, w kwestii zainteresowania historyków historią mówioną, wskazywał R.L. Filippelli w omówionym powyżej artykule, czyli rolą oral history jako świadectw historycznych. Na początku Moss pisze następująco: „[... jeśli oral history ma być godnym zaufania narzędziem badawczym, jeśli ma stać się szanowanym dowodem historycznym i ma uzasadniać narodowe stowarzyszenie o tej nazwie, to ci, którzy produkują oral history, naukowcy używający jej wytworu i instytucje finansujące jej projekty muszą mieć pewne środki do zrozumienia jej właściwej roli i do oceniania, co się dzieje na tym polu"162. Tekst dzieli się na

158 Tamże, s. 482.

159 Tamże.

160 Tamże, s. 483.

161 W.W. Moss, Oral History: An Appreciation, American Archivist, October 1977, Vol. 40, No. 4, s. 429-439.

162 Tamże, s. 429. 
trzy części zatytułowane: Dowodowa wartość historii mówionej, Lekcja oral history, Systematyczna ocena oral history.

W części pierwszej autor omawia relacje historii mówionej w stosunku do innych typów źródeł historycznych. Wymienia pięć ich rodzajów: dokumenty transakcyjne („transactionalrecords”), dokumenty selektywne („selectiverecords”), wspomnienia („recollections”), refleksje („reflections”) oraz analizy (,analysis”).

Dokumenty transakcyjne są nie tyle odbiciami wydarzeń, ile wydarzeniami, działaniami, akcjami samymi w sobie. Moss wymienia tu m.in. konstytucje, ustawy, umowy, akty notarialne, certyfikaty, patenty, instrukcje czy ogłoszenia, stanowiące źródła pierwotne, niezawierające w sobie żadnych interpretacji poza tymi nadanymi im przez obserwatora ${ }^{163}$.

Dokumenty selektywne opisują to, co dzieje się w danym momencie. Są to np. nagrania audio i wideo, stenograficzny zapis rozmów czy fotografie. Między rzeczywistością a dokumentem zachodzi proces selekcji lub interpretacji ${ }^{164}$.

Wspomnienia to relacje z pierwszej ręki opisujące jakieś wydarzenia, jednak nie są one dokonywane w trakcie dziania się tych wydarzeń, lecz później. Do wspomnień zaliczyć można pamiętniki, zeznania świadków, opowieści dziadków oraz relacje oral history. Ten typ dokumentów jest mniej wiarygodny niż dokumenty selektywne czy transakcyjne, jest za to szeroko dostępny. Według Williama W. Mossa nie należy jednak polegać na relacjach historii mówionej tak samo jak na materiałach z dwóch poprzednich grup. Mogą zawierać świadectwa przeszłości z drugiej ręki lub być oparte na pogłoskach i mogą być podkolorowane ze względu na wpływ różnych informacji na ten temat na świadka. Powody zniekształcenia relacji mogą być różne: świadek może chcieć ochronić swoją zasłużoną pozycję w historii lub sprzedać gazetę czy książkę ${ }^{165}$. Moss wymienia trzy poziomy wspomnienia jako źródła historycznego: poziom rzeczywistego wydarzenia, poziom ludzkiej pamięci oraz poziom dalszego selektywnego i interpretatywnego opisu, relacji powziętej z pamięci świadka/narratora. Może występować też czwarty poziom: pytania zadawane przez osobę przeprowadzającą wywiad oraz konkretny cel wywiadu. $Z$ tego powodu nagranie wywiadu nigdy nie może zostać pomylone z rze-

163 Tamże, s. 430.

164 Tamże.

165 Tamże, s. 431. 
czywistym wydarzeniem, które opisuje, ani nawet z pamięcią o tym wydarzeniu $^{166}$. Według Mossa tam, gdzie nie ma dokumentów transakcyjnych ani selektywnych, środki do poznania prawdy historycznej mogą dać zsumowane wywiady oral history, o ile jest ich dużo i zostały pobrane od przekrojowej grupy świadków. W takim wypadku wiarygodność źródeł mówionych może dosięgnąć nawet tej osiąganej przez dokumenty transakcyjne i selektywne ${ }^{167}$.

Kolejne dwa rodzaje dokumentów wymieniane przez Williama Mossa to refleksje (myśli konkretnych osób na temat przeszłości, zapisywane razem ze wspomnieniami w trakcie wywiadów oral history lub w pamiętnikach) oraz analizy (wyniki procesu przetwarzania informacji na temat przeszłości) ${ }^{168}$.

W drugiej części tekstu (Lekcja oral history), najkrótszej z wymienionych wcześniej trzech, Moss zawiera właściwie sens swojego tekstu, mówiąc o historii mówionej tak: „odpowiednio użyta może poczynić istotny wkład. Użyta nieodpowiednio może być psotna i destruktywna. Oral history, aby była jak najbardziej efektywna, musi sama w sobie mieć dobre oparcie w solidnej analizie oraz w gruntownej wiedzy i zrozumieniu wszystkich innych dostępnych do tematu źródeł"169.

Trzecia część artykułu (Systematyczna ocena oral history) zaczyna się od przywołania terminu „dokumentacja oralna”, „mówiona” („oral documentation”), do której należy oral history („zapis specjalnego rodzaju wydarzenia, wywiadu, w trakcie którego informacja historyczna, spostrzeżenia i opinie są celowo wyszukiwane i celowo zachowywane jako źródło historyczne"170). Inne rodzaje dokumentacji oralnej to zapisy wystąpień opartych na scenariuszu (np. przemów politycznych czy wystąpień teatralnych) oraz zapisy wydarzeń, w trakcie których uczestnicy wypowiadają się spontanicznie ${ }^{171}$.

W dalszej części artykułu Moss stara się przybliżyć procedurę krytyki relacji oral history. Na początku należy ustalić autentyczność i integralność nagrania oraz to, czy nagranie przedstawia autentyczne wydarzenie, czy zawiera nagranie performance'u. Należy wykazać się dużą dozą sceptycyzmu i najpierw ustalić, czy świadek jest wiarygodny. Dokonując analizy oral history, trzeba porównać informacje zawarte w wywiadzie (zarówno pytania, jak i od-

166 Tamże.

167 Tamże, s. 432.

168 Tamże.

169 Tamże, s. 433.

170 Tamże, s. 435.

171 Tamże. 
powiedzi) z informacjami podawanymi przez inne źródła, aby dowiedzieć się, czy osoba przeprowadzająca wywiad i osoba go udzielająca wiedzą, co mówią, czy znają się na tej materii ${ }^{172}$. Następnie trzeba ocenić trzy sfery wywiadu oral history: zawartość wywiadu, przebieg wywiadu oraz projekt historii mówionej (m.in. jakie są jego cele, założenia, jak dobierano osoby przeprowadzające wywiad i świadków historii, jakie stosowano procedury w trakcie tworzenia projektu, jakie są zasady udostępniania wywiadów) ${ }^{173}$.

Kolejnym tekstem opublikowanym w „American Archivist” dotyczącym historii mówionej jest rozmowa Lynn A. Bonfield z Arthurem M. Schlesingerem, Jr. ${ }^{174}$, historykiem, doradcą prezydentów Stanów Zjednoczonych J.F. Kennedy'ego i L.B. Johnsona, autorem publikacji o Johnie F. Kennedym i Robercie Kennedym (napisanych z użyciem relacji oral history), uczestnikiem projektu oral history w John F. Kennedy Library ${ }^{175}$.

W rozmowie Schlesinger zdradza tajniki swojej pracy jako historyka używającego w badaniach relacji oral history. Robiąc wywiady, nie nagrywał ich, lecz sporządzał jedynie notatki. Tłumaczy, że nie korzystał z urządzeń rejestrujących, bo wtedy trzeba by było zatrudnić kogoś do napisania transkrypcji, a dopiero potem sporządzić z tego notatki. On natomiast od razu, w trakcie wywiadu, notował i konsultował cytaty z narratorem. Zdradził również, że finalnie planuje zdeponować swoje notatki z wywiadów w Bibliotece Kennedy'ego $^{176}$.

Schlesinger opowiada również o znaczeniu historii mówionej - m.in. o tym, że jest to sposób uratowania materiału, do którego w innym wypadku żaden z historyków nie miałby dostępu, o tym również, jak bardzo relacje oral history wzbogacają naszą wiedzę o przeszłości. Jednocześnie podkreśla ograniczenia, które niesie ze sobą ta metoda, zwłaszcza ograniczenia wynikające z ułomności ludzkiej pamięci ${ }^{177}$.

W wywiadzie historyk ten porusza również temat swojego stosunku do nagrań oral history. Uważa on, że słuchanie nagrań jest czasochłonne, lecz jednocześnie przyznaje, że pewne niuanse zanikają w transkrypcie, jak np.

172 Tamże, s. 435-436.

173 Tamże, s. 437-439.

174 L.A. Bonfield, Conversation with Arthur M. Schlesinger, Jr.: The Use of Oral History, American Archivist, Fall 1980, Vol. 43, No. 4, s. 461-472.

175 Tamże, s. 461.

176 Tamże, s. 463.

177 Tamże, s. 465-466. 
ironiczny ton głosu narratora, który mógłby wpłynąć na sposób interpretacji wypowiadanego tekstu ${ }^{178}$.

Schlesinger pytany jest również o kwestie poufności i prywatności w oral history ${ }^{179}$, problemy związane $\mathrm{z}$ dostępem do oral history ${ }^{180}$, kwestię cytowania relacji1 ${ }^{181}$, a także odnosi się do rzeczy na ówczesne czasy (rok 1980) nowej - wywiadów rejestrowanych na wideo ${ }^{182}$.

O historii mówionej pisał w „American Archivist” również James E. Fogerty, w artykule zatytułowanym „Filling the Gap: Oral History in the Archives” („Wypełniając lukę: oral history w archiwach”) ${ }^{183}$.

Autor zauważa, że oral history została już zaakceptowana jako narzędzie używane w badaniach historycznych, jednak nie jest dostatecznie szanowana przez historyków, a wręcz uważa się ją za podejrzaną, wciąż podchodzi się z nieufnością do tej metody. Odpiera tę krytykę, porównując oral history do źródeł pisanych: korespondencji, wspomnień i pamiętników; te typy dokumentów są również podatne na pomyłki i manipulacje, a mimo to szerzej wykorzystywane przez badaczy ${ }^{184}$.

Fogerty sądzi, że oral history staje się koniecznością z powodu panującego w drugiej połowie wieku modelu zarządzania dokumentacją, z powodu zalewu dokumentacją o małej wartości informacyjnej ${ }^{185}$. Uważa ponadto, że zasoby archiwalne zawierają luki - nieudokumentowane okresy lub wydarzenia związane z działalnością twórcy zespołu. Dokumentacja papierowa nie zawiera również informacji dot. motywów postępowania, skazując historyka na domysły ${ }^{186}$. Projekt oral history mógłby poruszyć takie tematy, jak: finansowanie instytucji, relacje udziałowców, relacje na linii rząd-przemysł, sprawy socjalne, relacje wśród pracowników, strategie marketingowe. Tym sposobem ujawnia obraz organizacji jako zbiorowiska ludzi mających konkretne motywy, aspiracje, ideały ${ }^{187}$.

178 Tamże, s. 467.

179 Tamże, s. 468.

180 Tamże, s. 469.

181 Tamże, s. 470.

182 Tamże, s. 471.

183 J.E. Fogerty, Filling the Gap: Oral History in the Archives, American Archivist, Spring 1983, Vol. 46, No. 2, s. 148-157.

184 Tamże, s. 149.

185 Tamże, s. 150.

186 Tamże, s. 150-151.

187 Tamże, s. 153. 
Autor przedstawia historię mówioną jako potencjalnie najbardziej realną i użyteczną metodę wypełnienia luk w dokumentacji. Nie da się jednak w ten sposób uzupełnić wszystkich braków w archiwach, dlatego trzeba zdecydować, które zespoły archiwalne wymagają uzupełnienia, należy zanalizować zawartość zespołu i opisać występujące luki ${ }^{188}$.

James E. Fogerty zdaje sobie sprawę z tego, że ze względu na podejście archiwistów oraz brak środków finansowych i zaplecza osobowego oral history jest na końcu listy priorytetów, o ile w ogóle tam jest. Zwraca uwagę na problemy finansowe projektów oral history, nawet tych największych w University of Columbia i University of California, Berkeley ${ }^{189}$.

W tekście podkreśla się również znaczenie przygotowań do wywiadu i znajomości istniejących już do tematu materiałów źródłowych (papierowych) ${ }^{190}$. Według Fogerty’ego ważnym powodem organizowania projektów oral history jest nastawienie archiwów na elity ${ }^{191}$. Historia mówiona daje również możliwość udokumentowania działalności niewielkich, efemerycznych grup działających w latach 70., powstających wokół konkretnych spraw, np. dot. projektów społecznościowych, środowiska naturalnego, szkół publicznych. Wiele z nich nie zostawiło po sobie dokumentacji, a były istotnymi składnikami amerykańskiego życia społecznego ${ }^{192}$.

Ważne miejsce w tekście zajmuje również kwestia tego, kto powinien robić oral history - archiwista, który najlepiej zna istniejący już zasób, specjalnie zatrudniony historyk oralny („oral historian”) czy badacz, który potrzebuje wypełnić lukę w zasobie archiwalnym do celów swoich badań? Niestety, najczęściej jest to ten ostatni. Szuka on tylko informacji do swojego, wąskiego, tematu badań, nie przeprowadza szerszego wywiadu. Często wywiady te nie są deponowane w archiwach i nie mogą być szerzej dostępne i użyteczne dla innych badaczy ${ }^{193}$.

Fogerty uważa, że idealną sytuacją byłoby, gdyby zatrudniono etatowych historyków oralnych. W perfekcyjnym świecie archiwa same utworzyłyby stałe biuro oral history, zatrudniające profesjonalistów działających w porozumieniu z archiwistami. Archiwiści również mogliby zostać „oral historians”,

188 Tamże, s. 151-152.

189 Tamże, s. 153-154.

190 Tamże, s. 154.

191 Tamże, s. 155.

192 Tamże, s. 156.

193 Tamże. 
ze względu na znajomość zasobu archiwalnego i szerokie spojrzenie na zagadnienia (w przeciwieństwie do badaczy, szukających odpowiedzi na konkretne pytania) ${ }^{194}$.

Kolejnym artykułem o oral history, według mnie bardzo interesującym i poruszającym kwestię od zupełnie innej strony, jest tekst Thomasa L. Charltona pt. „Videotaped Oral Histories: Problems and Prospects” („Historie mówione nagrywane na wideo: problemy i szanse") ${ }^{195}$. Zgodnie z tytułem główna część artykułu poświęcona jest przedstawieniu plusów i minusów używania technologii wideo w rejestrowaniu wywiadów oral history.

Jak inni przed nim Charlton uważa, że zaakceptowano już obecność źródeł niepisanych, w tym obrazów uwiecznionych na taśmach, w badaniach naukowych. Jednocześnie jednak sądzi, że wciąż niewielu archiwistów uważa nagrania wideo za dokumenty o wartości historycznej ${ }^{196}$. Według niego użycie wideo przez historyków to wspaniała perspektywa, o ile nie będzie się tego czynić bezkrytycznie. Jednak problemem dla badaczy może być chaotyczność przemysłu wideo (o czym pisze w dalszej części tekstu) ${ }^{197}$.

Autor przedstawia krótką historię technologii wideo, od roku $1939^{198}$. Szczególnie ważne są jednak wydarzenia współczesne autorowi. W latach 80. spadające ceny sprzętu pozwoliły wielu osobom i organizacjom na posiadanie niewielkich, przenośnych kamer i odtwarzaczy wideo. Jedną z najważniejszych zmian w dziedzinie nagrywania wideo było wprowadzenie technologii VTR (videotaperecorder), kiedy kasety wideo zastąpiły kasety reel-to-reel ${ }^{199}$.

Historycy zajmujący się historią mówioną byli na początku sceptyczni. Podejrzewali, że ogromny, przytłaczający sprzęt przyniesiony na miejsce wywiadu przestraszy i onieśmieli narratora. Zmienili swe nastawienie po wprowadzeniu na rynek VTR, które szybko zostało również zaangażowane do prac lokalnych historyków ${ }^{200}$.

Po krótkim przedstawieniu historii tej technologii autor przechodzi do przybliżenia zalet używania jej w ramach metody oral history. Charlton zwra-

194 Tamże, s. 157.

195 T.L. Charlton, Videotaped Oral Histories: Problems and Prospects, American Archivist, Summer 1984, Vol. 47, No. 3, s. 228-236.

196 Tamże, s. 229.

197 Tamże.

198 Tamże.

199 Tamże, s. 229-230.

200 Tamże, s. 230. 
ca uwagę na fakt, że zapis wideo umożliwia zachowanie głosu i wyglądu narratora, tym samym przekazuje również sygnały niewerbalne, gesty, cechy charakteru. Są to wizualne atrybuty sprawiające, że oral history staje się interesująca ${ }^{201}$. Autor zauważa też, że różne wizualne aspekty mogą odmiennie oddziaływać na oglądającego: wielkość i typ pomieszczenia, w którym odbywa się wywiad; dystans pomiędzy narratorem a osobą zadającą pytania; jakaś dekoncentrująca aktywność w bliskim otoczeniu wywiadu; rekwizyty na sto$\mathrm{le}^{202}$. Obraz wywiadu może wpłynąć na odczytanie przez badacza zawartego w nim kodu lingwistycznego, a tym samym wpłynąć na jego interpretację ${ }^{203}$. Dzięki takiemu przekazowi można według Charltona nakreślić portret psychologiczny narratora ${ }^{204}$. Należy jednak pamiętać, że nagranie wideo również musi zostać skonfrontowane z innymi źródłami, ponieważ może ono ujawnić niektóre tylko cechy osobowości relatora, a nie wszystkie ${ }^{205}$.

Według autora szczególną wagę mogą mieć nagrania wideo w przypadku rejestrowania wywiadów z np. rzemieślnikami czy artystami, którzy używają wielu gestów, opisując swoją pracę ${ }^{206}$. Co ciekawe, Charlton słusznie przewiduje rozwój technologii: dalszą miniaturyzację kamer wideo, polepszenie jakości obrazu, wydłużenie żywotności taśm wideo ${ }^{207}$.

Niestety, oprócz wymienionych powyżej korzyści istnieją również ograniczenia i problemy związane z tą metodą rejestrowania wywiadów historii mówionej. Najnowszy sprzęt dostępny na rynku jest skomplikowany i trudny do ocenienia. Producenci oferują wiele rodzajów rejestratorów i taśm magnetycznych, trudno dokonać wyboru między nimi ${ }^{208}$. Co więcej, niewiele archiwów czy bibliotek ma budżet na tyle duży, aby móc sobie pozwolić na kupienie i utrzymanie rejestratorów i odtwarzaczy do kilku różnych rodzajów taśmy magnetycznej. Ponadto wysoki jest koszt kopiowania i przetwarzania tych materiałów, a producenci oferują różne formaty nagrywania wideo ${ }^{209}$.

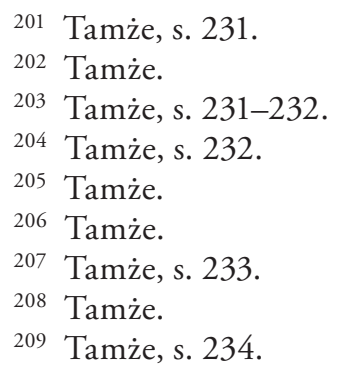


Według Thomasa L. Charltona udokumentowany na taśmie wideo powinien zostać i narrator, i pytający. W wariancie idealnym wywiad powinny nagrywać trzy kamery (jedna skierowana na udzielającego wywiadu, druga na przeprowadzającego wywiad, a trzecia na nich dwóch jednocześnie) ${ }^{210}$.

Autor porusza również kwestię integralności nośników. Taśmy wideo są narażone na stopniowe pogarszanie się jakości zapisanego obrazu wraz z kolejnymi odtworzeniami. Dlatego Charlton zaleca kopiowanie taśm, aby zapewnić egzemplarz do publicznego odtwarzania oraz egzemplarz zabezpieczający. Zwraca on również uwagę na fakt, że niewiele wiadomo o żywotności tego typu nośnika ${ }^{211}$.

Autor zdaje sobie sprawę, że ekwipunek służący do nagrywania może być w trakcie wywiadu przytłaczający, może zburzyć atmosferę intymności i zaufania. Ponadto może popchnąć narratora do grania przed kamerą. Może również stać się źródłem dekoncentracji i rozdrażnienia ${ }^{212}$.

Wideo pokazuje to, czy ktoś jest zmęczony, czy trzyma dobrą posturę ciała, czy jest zdenerwowany lub zestresowany. Charlton zastanawia się nad kwestią natury etycznej: czy nagrania wideo powinny być edytowane w poszukiwaniu fragmentów, które stawiają narratora w złym świetle lub zniechęcają do uczestniczenia w projektach oral history? ${ }^{213}$

W swoim artykule Charlton zastanawia się również nad tym, w jakich sytuacjach historyk powinien zrezygnować z nagrywania wideo na rzecz audio. Zauważa ponadto, że nagrywanie wideo oral history może wymagać sporządzania innych formularzy umów niż w przypadku audio oral history ${ }^{214}$.

O praktycznych aspektach zakładania projektu historii mówionej mówi następny tekst autorstwa Augustine’a W.C. Msiski pt. „An Attempt to Establish an Oral History Project in the University of Zambia Library, Lusaka Campus” („Próba utworzenia projektu oral history w bibliotece Uniwersytetu Zambii, Kampus Lusaka") ${ }^{215}$. Krótko opisuje losy projektu historii mówionej powstałego w Zambii w roku 1979. Przybliża m.in. perypetie związane z za-

210 Tamże.

211 Tamże, s. 235.

212 Tamże.

213 Tamże.

214 Tamże, s. 235-236.

215 A.W.C. Msiska, An Attempt to Establish an Oral History Project in the University of Zambia Library, Lusaka Campus, American Archivist, Winter 1987, Vol. 50, No. 1, s. $142-146$. 
kupem sprzętu potrzebnego do nagrywania wywiadów (np. nieprzewidziany w kosztorysie wzrost cen ${ }^{216}$ oraz biurokratyczne procedury związane z zakupem sprzętu elektronicznego z zagranicy ${ }^{217}$ ). Refleksji natury historycznej czy archiwistycznej jednak w tym tekście próżno szukać.

Kolejny warty wspomnienia tekst to artykuł Bruce'a H. Bruemmera pt. „Access to Oral History: A National Agenda” („Dostęp do oral history: program narodowy") $)^{218}$.

$\mathrm{Na}$ początku autor zauważa, że wiele projektów oral history zajmowało się głównie dokumentowaniem nieudokumentowanego, nie przywiązując jednak potem żadnej wagi do dostępu do tych danych. Wyjątkami są programy wydające przewodniki. Większość programów jednak nie ma zorganizowanej kontroli nad swoimi zasobami. W USA historycy oralni są przede wszystkim jej producentami, a w niemal żadnym stopniu jej kuratorami. Kiedy już powstanie finalny produkt (książka, artykuł...), nie przywiązują oni żadnej niemalże wagi do edytowania, opisu czy udostępniania wywiadu. Dominacja producentów nad kuratorami widoczna jest w liczbach: w 1987 r. na konferencji Oral History Association tylko 3 z 36 sesji poświęcone były zarządzaniu kolekcjami oral history; w 1991 - 3 z $51^{219}$.

Bruemmer uważa, że jest w tym również wina archiwistów, dla których oral history znajduje się na peryferiach ich zasobów archiwalnych, a zajmowanie się wywiadami leży na końcu listy priorytetów. Również literatura nie zawiera zbyt wielu informacji dot. zarządzania nagraniami oral history. Książka Fredericka Stielowa „The Management of Oral History Sound Archives” z 1985 roku zawiera wg autora artykułu informacje nieaktualne oraz niefortunne błędy merytoryczne ${ }^{220}$.

W dalszej kolejności autor przedstawia swój pogląd na miejsce oral history w badaniach historycznych i stosunek wywiadów do dokumentacji pisanej: „dobra historia mówiona nie tylko uzupełnia dokumenty pisane, ale również jest kluczem do zrozumienia dokumentów tradycyjnie gromadzonych przez

216 Tamże, s. 142-143.

217 Tamże, s. 143.

218 B.H. Bruemmer, Access to Oral History: A National Agenda, American Archivist, Fall 1991, Vol. 54, No. 4, s. 494-501.

219 Tamże, s. 495.

220 Tamże. 
archiwistów. [...] natura nowoczesnej dokumentacji wymaga historii mówionej jako składnika badania historycznego"221.

Według Bruemmera w wielu zasobach archiwalnych już teraz znajdują się materiały oral history, nie są one jednak udostępniane ${ }^{222}$. Uważa on, że obowiązkiem archiwisty jest skłaniać ludzi do korzystania ze źródeł pierwotnych, w tym oral history ${ }^{223}$, toteż w dalszej części tekstu omawia on metody „przyciągania” użytkowników do historii mówionej.

Typowym środkiem do pozyskiwania użytkowników jest drukowany przewodnik po materiałach oral history. Zawiera on krótki opis każdego wywiadu, zazwyczaj zawiera też indeks. Wadą takiego publikowanego przewodnika jest to, że zawarte w nim informacje szybko stają się nieaktualne, głównie dlatego, że zasoby oral history wciąż się powiększają 224. Dobrym środkiem służącym popularyzacji zasobu są również regionalne i ogólnopaństwowe przewodniki, np. „National Union Catalog: Manuscript Collections" (NUCMC). Niestety w kwestii relacji oral history takie przewodniki poniosły fiasko, ponieważ było w nich za mało haseł - instytucje posiadające w swoich zasobach oral history nie zgłaszały ich do publikacji ${ }^{225}$. Według autora lepszym sposobem na dystrybuowanie treści o posiadaniu relacji historii mówionej są komputerowe bazy danych, narodowe i regionalne bazy bibliograficzne ${ }^{226}$.

Bruce H. Bruemmer stworzył również ogólnonarodowy program, którego celem jest poprawienie dostępu do historii mówionej. Po pierwsze proponuje on ustanowienie formatu USMARC AMC (Format for Archival and Manuscripts Control) jako minimum opisu oral history. Według autora AMC jest formatem idealnie nadającym się do opisu wywiadów oral history, dużo lepiej niż formaty służące do opisu książek czy czasopism. Można na bieżąco aktualizować informacje, w przeciwieństwie do drukowanego przewodnika. Dlaczego więc nie używa się tego formatu do opisu relacji oral history? Bruemmer uważa, że winne jest podejście archiwistów, niechętnych podejmowaniu działań w stosunku do oral history. Ponadto trzeba by dostosować systemy katalogowania do formatu MARC AMC, a sprawdzanie nazw

221 Tamże, s. 496.

222 Tamże.

223 Tamże.

224 Tamże, s. 496.

225 Tamże, s. 497.

226 Tamże. 
i tematów (czy pasują do nowego standardu) dokonywane w trakcie wdrażania formatu wymagałoby wielkiej pracy źródłowej ${ }^{227}$. W skład opisu powinny wejść następujące pola: autor, tytuł, abstrakt, tematy poruszane w trakcie wywiadu. Autor uważa, że repozytorium, które nie może zapewnić nawet tak niewielkiego poziomu opisu, powinno zastanowić się nad swoim zaangażowaniem w oral history. Oczywiście wykonania takiego zadania nie można wymagać od niewielkich, niewspieranych przez profesjonalistów programów ${ }^{228}$. Krok w stronę usystematyzowania opisów relacji historii mówionej podjęły już duże amerykańskie repozytoria oral history jak Columbia, the Bancroft Library, Brigham Young, Louisiana State i Charles Babbage Institute $^{229}$. Drugim punktem programu proponowanego przez Bruemmera jest zresztą stworzenie i upublicznienie wskazówek służących ujednoliceniu rekordów wprowadzanych za pomocą MARC AMC ${ }^{230}$.

Trzecią propozycją autora jest ustanowienie programu międzybibliotecznych wypożyczeń oral history. Przeszkodą w wypożyczaniu relacji historii mówionej jest możliwe nieodpowiednie obchodzenie się z nimi przez wypożyczających, niebędących wtedy pod bezpośrednią opieką kuratora zbiorów, z których pochodzi dana relacja. Oral history może jednak być wypożyczana w nieoryginalnej formie, tj. jako kopia nagrania lub kopia transkryptu. System służący wypożyczaniu powinien brać pod uwagę różne zasady użycia wywiadów. Zazwyczaj repozytoria nie zezwalają na kopiowanie całości transkryptu. Takie repozytorium powinno mieć gwarancję, że w instytucji wypożyczającej wywiad nie nastąpią żadne niepożądane czynności ${ }^{231}$.

W kolejnym, czwartym punkcie swojego programu poprawy dostępu do oral history Bruce H. Bruemmer postuluje zbadanie nowych technologii w celu poprawienia dostępności informacji zawartych w relacjach oral history. Jako przykład tego typu działań autor podaje Williama Schneidera z Uniwersytetu Alaski, który powołał do życia Projekt Jukebox (pol. szafa grająca). Jest to hipermedialna aplikacja, dzięki której transkrypt, nagranie, grafiki i fotografie docierają do użytkownika jednocześnie. Niestety, taka technologia jest poza zasięgiem znacznej większości projektów oral history ${ }^{232}$. Można jednak

227 Tamże, s. 498.

228 Tamże.

229 Tamże, s. 499.

230 Tamże.

231 Tamże, s. 499-500.

232 Tamże, s. 500-501. 
używać technologii w tańszy sposób. Charles Babbage Institute udostępnia badaczom dyskietki z tekstem transkryptu zapisanym w przeszukiwalnym edytorze tekstu, dzięki temu wyzbyli się potrzeby indeksowania całego wywiadu $^{233}$. „Proszę jednak zauważyć, że te dwa przykłady wymagają stworzenia transkrypcji, jest to wymóg, którego wiele repozytoriów nie jest w stanie spełnić" ${ }^{34}$. W tym miejscu Bruemmer daje znać, że zmienia się podejście do transkryptu. Jest on jedynie źródłem drugiego stopnia, podstawą stała się taśma z nagraniem wywiadu, a to za sprawą upowszechnienia się technologii nagrywania dźwięku lub obrazu i dźwięku na taśmy magnetyczne.

Ostatnim postulatem autora jest wspieranie odpowiedniego dostępu społeczności oral history do zbiorów oral history. Widzi on potrzebę zmiany nastawienia wśród historyków zajmujących się historią mówioną. Bruemmer uważa, że należy stworzyć pomost między nimi jako producentami oral history a ich kuratorami. Archiwiści powinni spotykać się z historykami oralnymi oraz angażować ich w fora archiwalne, aby uświadamiać ich co do tego, jak ważny jest dostęp do wywiadów ${ }^{235}$.

Na podstawie przeprowadzonej powyżej analizy treści osiemnastu tekstów opublikowanych w czasopiśmie „American Archivist” można wysnuć kilka wniosków dotyczących obecności tematyki historii mówionej w dyskursie archiwistycznym w Stanach Zjednoczonych Ameryki Północnej w drugiej połowie XX wieku.

Przede wszystkim warto zauważyć, że najwięcej miejsca poświęca się w niniejszych opracowaniach tematowi relacji oral history jako źródeł historycznych. Poruszana jest zwłaszcza kwestia wiarygodności historii mówionej, w tym również tego, w jaki sposób tworzyć tego typu źródła, aby były jak najbardziej wiarygodne. W związku z tym autorzy proponują różnego rodzaju rozwiązania, mające zapewnić taki status wywiadom oral history. Zaleca

233 Tamże, s. 501. Również obecnie pokutuje takie przekonanie, że tekst transkrypcji, całkowicie przeszukiwalny (a współcześnie, w erze komputerów, jest to przecież powszechne) w zupełności zastępuje opis wywiadu za pomocą słów kluczowych. Niestety tak nie jest, ponieważ język naturalny, używany przez narratora, i język wyszukiwawczy, używany przez użytkownika w zapytaniu wyszukiwawczym, nie są tożsame. W praktyce można powiedzieć po prostu, że wypowiedź świadka historii nie będzie zawierała takich kategorii znaczeniowych jak „Akcja Burza”, „Holokaust”, „Einsatzgruppen”, „rewolucja seksualna”, „diaspora żydowska” etc., podczas gdy takie kategorie będą używane przez użytkownika w trakcie budowania zapytania wyszukiwawczego.

234 Tamże, s. 501.

235 Tamże. 
się różne procedury przygotowywania się do rozmowy z narratorem, przeprowadzania wywiadu, zadawania pytań, wchodzenia w interakcję ze świadkiem historii.

Autorzy używają również różniących się od siebie technik służących zapisaniu przebiegu wywiadu: od odręcznych notatek sporządzanych w trakcie rozmowy i tuż po niej, poprzez nagrywanie wywiadu, ale jedynie w celu sporządzenia jego transkrypcji (po czym nagranie usuwa się, w całości lub zostawiając tylko niewielkie fragmenty), aż po nagranie wywiadu (audio lub w latach późniejszych wideo), które staje się źródłem pierwotnym, nieusuwalnym, a jego transkrypcja jest tylko narzędziem ułatwiającym dostęp do treści wywiadu. Tym samym, w pewnym momencie zmienia się właściwie rozumienie oral history jako źródła historycznego. Zmiana polega na uznaniu za właściwe źródło nagrania samego wywiadu, podczas gdy wcześniej, przed pojawieniem się w powszechnym użytku technologii VTR w latach 80., za wywiad jako źródło uznawano jego zapis na papierze, tj. notatki sporządzone w jego trakcie lub transkrypcję wywiadu.

Procederowi transkrybowania wywiadów również poświęca się w „American Archivist” trochę miejsca, przede wszystkim w kontekście wcześniej już wspomnianym, czyli uwiarygodnienia historii mówionej jako źródła historycznego. Pod dyskusję poddawany jest przede wszystkim poziom ingerencji narratora $\mathrm{w}$ transkrypt (oraz, ewentualnie, poziom ingerencji autora transkryptu).

W publikacjach można dostrzec również inne pomysły na to, jak uczynić wywiad oral history wartościowym źródłem w służbie historii. Toteż pojawiały się w nich propozycje sporządzenia bibliografii publikacji, z których korzystał przed wywiadem przeprowadzający go (a nawet udzielający wywiadu), czy też dołączenia do wywiadu notatki zawierającej m.in. informacje o miejscu przeprowadzenia rozmowy, wyglądzie narratora, atmosferze.

Warto jednak zauważyć, że przede wszystkim w pierwszej połowie analizowanego okresu (tj. w trzeciej ćwierci XX wieku) zagadnienia tego typu jak odpowiedni opis relacji czy sposób transkrypcji pojawiają się nie w kontekście ułatwienia (czy w ogóle - umożliwienia) dostępu do oral history, ale w kontekście wywołania i późniejszego uformowania źródła w taki sposób, aby podnieść jego rangę w oczach profesjonalnych historyków.

Zresztą pewnego rodzaju przekonywanie historyków do wykorzystywania historii mówionej w swoich badaniach również znajduje swoje miejsce w zanalizowanych przeze mnie publikacjach. $Z$ jednej strony podkreśla się 
(zwłaszcza w tekstach wcześniejszych) ewolucję w zarządzaniu dokumentacją, a także rewolucję technologiczną, powodujące zalewanie historyka czasów najnowszych masowymi źródłami niosącymi pojedynczo niewielkiej wartości informacje oraz zanik tradycji pisania pamiętników czy listów, na co odpowiedzią ma być właśnie historia mówiona. Z drugiej strony nie bez echa pozostają wymagające nowych rodzajów źródeł, nowe trendy badawcze w historii: historia przemysłu, medycyny, pracy, imigrantów, mniejszości etc. Tutaj również podkreśla się konieczną obecność relacji.

Kolejnym zagadnieniem poruszanym w „Amerykańskim Archiwiście” jest relacja wywiadów oral history z dokumentacją tradycyjną (pisaną). Podkreśla się potrzebę dogłębnych studiów wstępnych na podstawie już istniejącej dokumentacji papierowej, a dopiero potem, w związku z uzyskaną wiedzą i wykrytymi lukami w tejże dokumentacji, przejście do wywołania źródeł „nietradycyjnych”, czyli m.in. historii mówionej. W konsekwencji opracowaniu w niniejszych tekstach podlega również zagadnienie krytyki źródeł. Tutaj można dostrzec, z jednej strony opisane wcześniej przeze mnie procedury mające tę krytykę źródeł ułatwić i sprofesjonalizować, z drugiej - podkreślanie przez autorów, że innego typu źródła, np. listy czy pamiętniki, również są pisane z perspektywy czasu i są subiektywne, a mimo to historycy sięgają do nich chętniej.

Nie bez znaczenia jest również obecność prób definiowania oral history. Pojawiają się one w analizowanych tekstach, jednak przede wszystkim w początkowym okresie, potem cichną, co zapewne ma związek z „oswojeniem” się środowiska ze zjawiskiem historii mówionej oraz pojawieniem się oficjalnej definicji zaproponowanej przez Oral History Association pod koniec lat 60.

Pragnę w tym miejscu podkreślić, że właściwie wszystkie przytoczone powyżej uogólnienia mają charakter historyczny, a nie archiwistyczny. Dopiero po pewnym czasie (i w mniejszej objętości) w „American Archivist” pojawiają się wątki związane z działalnością archiwalną i obecnością relacji historii mówionej w archiwach.

Do poruszanych w omawianych tekstach kwestii należy na pewno problem przekazywania (a właściwie: nieprzekazywania) przez historyków relacji oral history, nagranych przez nich w ramach prowadzenia swoich badań historycznych, do archiwów czy innego rodzaju instytucji kultury (np. bibliotek), co dałoby wgląd szerszej społeczności do tych wywołanych przez historyków źródeł. Autorzy podkreślają z jednej strony niechęć do dzielenia się $\mathrm{z}$ innymi swoimi zapisami wywiadów. $Z$ drugiej strony w ogóle zauważają, że 
często oral history tworzone jest przez historyków „pod artykul” czy też „pod książkę”, tzn. do konkretnego, wąsko zarysowanego tematu historycznego. Tak zebrane relacje często po opublikowaniu finalnego produktu (właśnie artykułu lub książki, czy też po zdobyciu stopnia/tytułu naukowego) trafiają do szuflady, a nawet jeśli zostaną przekazane do np. archiwum i szerzej udostępnione, to i tak nie przyniosą innym badaczom dużego pożytku.

W ogóle tematyka udostępniania historii mówionej ze wszystkich kwestii archiwistycznych poruszana jest chyba najszerzej. W ramach tej problematyki pojawia się kwestia np. form udostępniania przez archiwa informacji o posiadanych materiałach oral history, czyli kwestia pomocy informacyjno-wyszukiwawczych - gdzie i w jaki sposób tego typu informacje powinny być publikowane oraz jak powinien wyglądać opis oral history (tutaj naturalnie należy przyjąć, że zagadnienie opisu relacji zostaje poruszone w ramach udostępniania historii mówionej). Autorzy, jeśli już poruszają problem udostępniania, jak jeden mąż namawiają do zapewnienia wolnego dostępu do relacji, również do zwiększenia dostępności poprzez system wypożyczania ich między instytucjami. Warto jednak zauważyć, że w tekstach tych mówi się o dostępie przede wszystkim dla uczonych (czy szerzej: środowiska akademickiego), a nie o możliwości wykorzystania wywiadów przez szerokie rzesze zwykłych obywateli.

Swój mały zakątek w omówionych przeze mnie publikacjach ma też kwestia miejsca archiwów i archiwisty w działalności związanej z nagrywaniem oral history, a także problem stosunku archiwistów do tej metody wywoływania źródeł. Żadne jednak z tych zagadnień, kluczowych jak się wydaje dla zawodu archiwisty, nie zostało szerzej rozwinięte.

Autorzy nieraz wspominają również o aspektach prawnych, to jest m.in. o podpisaniu z narratorem odpowiednio skonstruowanych umów, tak, aby potem relacja oral history mogła być swobodnie udostępniana badaczom i przez nich wykorzystywana. Próżno jednak szukać zagadnień typowo archiwistycznych, a mających, moim zdaniem, pewien związek z obecnością oral history w archiwach; chodzi tutaj o kwestię zespołowości oraz terytorialności historii mówionej (zwłaszcza ta druga kwestia wydaje się interesująca). Archiwista nie znajdzie w tych publikacjach również nic o przyziemnym problemie przechowywania oral history. Można naturalnie założyć, że stosuje się odpowiednio praktyki związane z przechowywaniem innych rodzajów dokumentacji na tych samych nośnikach, na których przechowuje się oral history, tj. przykładowo na taśmach reel-to-reel, kasetach magnetofonowych 
czy płytach $\mathrm{CD}$, toteż o przechowywaniu konkretnie oral history nie warto wspominać. Jednak nawet takiego truizmu w niniejszych artykułach nie znajdziemy ${ }^{236}$. Za to wraz z rozwojem nowoczesnych technologii pojawiają się innego rodzaju zagadnienia, takie jak: wideofilmowanie relacji, mnogość typów i formatów zapisu magnetycznego, kwestia użycia baz danych w udostępnianiu oral history, rola wyszukiwania pełnotekstowego.

Jak już wspomniałam na samym początku, polską literaturę z zakresu archiwistyki zajmującą się zagadnieniem relacji historii mówionej można właściwie ograniczyć do dwóch głównych pozycji ${ }^{237}$. Ufam jednak, że z czasem, również w związku ze wspominanym przeze mnie wcześniej antropologicznym zwrotem w archiwistyce, tekstów poruszających ten temat pojawi się więcej.

Sądzę, że polscy archiwiści na łamach swoich czasopism archiwistycznych nie będą musieli borykać się z problemem przekonywania historyków ${ }^{238}$ (a może i samych siebie?) do traktowania relacji jako pełnoprawnego źródła historycznego ${ }^{239}$, co pochłonęło najwięcej sił piszących o historii mówionej w „American Archivist”. Ta dyskusja na łamach polskiej literatury historycznej już się toczyła, obficie udokumentowana publikacjami. Nie twierdzę, rzecz jasna, że archiwiści nie powinni się „wtrącać” w tę dyskusję, ale raczej, że bardziej pilną sprawą jest zajęcie się historią mówioną z perspektywy archiwistów, to pole badawcze jest bowiem prawie nietknięte.

236 Ponadto kwestia przechowywania (ale też i opisu czy udostępniania) może skomplikować się w przypadku dwoistości relacji, tj. istnienia dwóch oryginałów: nagrania oraz podpisanej przez świadka transkrypcji.

237 A. Żeglińska, dz. cyt.; I. Lewandowska, A. Bogdanowicz, Komputerowe metody archiwizacji relacji ustnych, http://archiwa.gov.pl/images/stories/file/pdf/komputerowe_ metody.pdf (dostęp z dnia 14.12.2014 r.).

238 Przynajmniej niektórzy są już z resztą do wartości historii mówionej przekonani, powstają przecież w Polsce prace historyczne oparte w dużej mierze na oral history; patrz np. J. Eisler, Marzec 1968. Geneza, przebieg, konsekwencje, Warszawa 1991; E. Szpak, Między osiedlem a zagrodą. Życie codzienne mieszkańców PGR-ów, Warszawa 2005; M. Mazurek, Socjalistyczny zaktad pracy. Porównanie fabrycznej codzienności w PRL i NRD u progu lat sześćdziesiątych, Warszawa 2005; B. Klich-Kluczewska, Przez dziurke od klucza. Życie prywatne w Krakowie 1945-1989, Warszawa 2005; D. Jarosz, Mieszkanie się należy...: studium z peerelowskich praktyk spotecznych, Warszawa 2010.

239 Por. D. Kałwa, Historia mówiona w krajach postkomunistycznych. Rekonesans, Kultura i Historia, nr 18/2010, http://www.kulturaihistoria.umcs.lublin.pl/archives/1887 (dostęp z dnia 14.12.2014 r.). 
Bibliografia

Anderson R.J., Managing Change and Chance: Collecting Policies in Social History Archives, „American Archivist”, Vol. 48, No. 3, Summer 1985, s. 296-303.

Benison S., Reflections on oral history, „American Archivist”, January 1965, Vol. 28, No. 1, s. 71-77.

Bonfield L.A., Conversation with Arthur M. Schlesinger, Jr.: The Use of Oral History, „American Archivist”, Fall 1980, Vol. 43, No. 4, s. 461-472.

Bornet V.D., Oral history can be worthwhile, „American Archivist”, July 1955, Vol. 18, No. 3, s. 241-253.

Bornet V.D., The Manuscripts of Social Welfare, „American Archivist”, Vol. 23, No. 1, January 1960 , s. 33-48.

Bruemmer B.H., Access to Oral History: A National Agenda, „American Archivist”, Fall 1991, Vol. 54, No. 4, s. 494-501.

Cappon L.J., The Archivist as Collector, „American Archivist”, October 1976, Vol. 39, No. 4, s. 429-435.

Charlton T.L., Videotaped Oral Histories: Problems and Prospects, „American Archivist”, Summer 1984, Vol. 47, No. 3, s. 228-236.

Colman G.P., Oral History - An Appeal for More Systematic Procedures, „American Archivist", January 1965, Vol. 28, No. 1, s. 79-83.

Culbert D.H., Family History Projects: The Scholarly Value of the Informal Sample, „American Archivist", Vol. 38, No. 4, October 1975, s. 533-541.

Edmunds H.E., The Ford Motor Company Archives, „American Archivist”, Vol. 15, No. 2, April 1952, s. 99-104.

Fenn, Jr. D.H., Launching the John F. Kennedy Library, „American Archivist”, Vol. 42, No. 4, October 1979, s. 429-442.

Filippelli R.L., Collecting the Records of Industrial Society in Great Britain: Progress and Promise, „American Archivist”, Vol. 40, No. 4, October 1977, s. 403-411.

Filippelli R.L., Oral History and the Archives, „American Archivist”, October 1976, Vol. 39, No. 4, s. 479-483.

Fiternicka-Gorzko M., Historia mówiona: od metody historycznej do interdyscyplinarnego podejścia badawczego, „Opuscula Sociologica” nr 2/2012, s. 5-25.

Fogerty J.E., Filling the Gap: Oral History in the Archives, „American Archivist”, Spring 1983, Vol. 46, No. 2, s. 148-157.

Fry A.R., Baum W., A Janus Look at Oral History, „American Archivist”, October 1969, Vol. 32, No. 4, s. 319-326.

Hagan W.T., Archival Captive - The American Indian, „American Archivist”, Vol. 41, No. 2, April 1978, s. 135-142. 


\section{Magdalena WiśniewsKa}

Ham F.G., The Archival Edge, „American Archivist”, January 1975, Vol. 38, No. 1, s. $5-13$.

Henry L.J., Collecting Policies of Special-Subject Repositories, „American Archivist”, Vol. 43, No. 1, Winter 1980, s. 57-63.

Juliani R.N., The Use of Archives in the Study of Immigration and Ethnicity, „American Archivist", Vol. 39, No. 4, October 1976, s. 469-477.

Kałwa D., Historia mówiona w krajach postkomunistycznych. Rekonesans, „Kultura i Historia” nr 18/2010, http://www.kulturaihistoria.umcs.lublin.pl/archives/1887 (dostęp z dnia 14.12.2014 r.).

Kreneck T.H., Documenting a Mexican American Community: The Houston Example, „American Archivist”, Vol. 48, No. 3, Summer 1985, s. 272-285.

Kurkowska M., Archiwa pamięci - oral history, „Historyka”, t. XXVIII, 1998, s. 67-76.

Kyvig D.E., Family History: New Opportunities for Archivists, „American Archivist”, Vol. 38, No. 4, October 1975, s. 509-519.

Lathrop Gilb C., Tape-Recorded Interviewing: Some Thoughts From California, „American Archivist”, October 1957, Vol. 20, No. 4, s. 335-344.

Lewandowska I., Bogdanowicz A., Komputerowe metody archiwizacji relacji ustnych, http://archiwa.gov.pl/images/stories/file/pdf/komputerowe_metody.pdf (dostęp z dnia 14.12.2014 r.).

Mbaye S., Oral Records in Senegal, „American Archivist”, Vol. 53, No. 4, Fall 1990, s. $566-574$.

McCann White H., Thoughts on oral history, „American Archivist”, January 1957, Vol. 20, No. 1, s. 19-30.

Mifflin J., "Clothing Facts in Words”: Archivists and the Holocaust, „American Archivist”, Vol. 61, No. 2, 1998, s. 453-474.

Miller F.M., Social History and Archival Practice, „American Archivist”, Vol. 44, No. 2, Spring 1981, s. 113-124.

Morrissey Ch.T., Truman and the Presidency - Records and Oral Recollections, „American Archivist", January 1965, Vol. 28, No. 1, s. 53-61.

Moseley E., Women in Archives: Documenting the History of Women in America, „American Archivist", Vol. 36, No. 2, April 1973, s. 215-222.

Moseley E.S., Sources for the „New Women's History”, „American Archivist”, Vol. 43, No. 2, Spring 1980, s. 180-190.

Moss W.W., Oral History: An Appreciation, „American Archivist”, October 1977, Vol. 40, No. 4, s. 429-439.

Msiska A.W.C., An Attempt to Establish an Oral History Project in the University of Zambia Library, Lusaka Campus, „American Archivist”, Winter 1987, Vol. 50, No. 1, s. $142-146$. 
Oral History and Archivists: Some Questions to Ask, by the Committee on Oral History of the Society of American Archivists, „American Archivist”, July 1973, Vol. 36, No. 3, s. 361-365.

Phillips F., Congresional Papers: Collection Development Policies, „American Archivist”, Vol. 58, No. 3, Summer 1995, s. 258-269.

Popplestone J.A., M. White MacPherson, The Archives of the History of American Psychology, „American Archivist”, Vol. 34, No. 1, January 1971, s. 13-19.

Stewart W.J., The Sources of Labor History: Problem and Promise, „American Archivist”, Vol. 27, No. 1, January 1964, s. 95-102.

Swain D.C., Problems for Practitioners of Oral History, „American Archivist”, January 1965, Vol. 28, No. 1, s. 63-69.

Wallot J.P., Archival Oneness in the Midst of Diversity: A Personal Perspective, „American Archivist", Vol. 59, No. 1, Winter 1996, s. 14-29.

Żeglińska A., Relacje oral history jako obiekty archiwalne, „Archiwa -Kancelarie - Zbiory”, nr 2(4)/2011, s. 145-154.

Su m m a ry

American archivists on oral history - review of the subject of texts published in the second half of the 20th century in pages of "The American Archivist”

In its first part, the article consists of a detailed discussion on eighteen texts on oral history published in the second half of the 20th century in the leading American archival journal „The American Archivist”. The second part are conclusions concerning the presence of the subject of oral history in archival discourse in the United States in the latter half of the 20th century. In the analyzed texts a lot of space has been given to the character of oral history interviews as historical sources. Especially, the question of reliability of oral history has been raised, as well as ways of guaranteeing it (e.g. through a proper description). Moreover, in many cases these texts attempt to persuade their readers to use oral history in their research. Also, it may be noticed, that at some point the understanding of oral history as historical source changes - an audio or video recording of the interview becomes a source itself, and not notes made while carrying it out or its transcription. Also relations between oral history and traditional (paper) records are an important issue in discussions of the American authors. The analysis of the articles also indicates that the authors were interested more in issues of the historical nature, than of the archival one. Those latter are mostly providing access to oral history materials. But also the question of the role of archives and archivists in recording oral history is touched. Discussion on the issue of storing oral history is not present at all. 